pag

Business School

WORKING PAPER SERIES

\begin{tabular}{c|l} 
Working Paper & $\begin{array}{l}\text { Do Minimum Wages Affect Firms } \\
\text { Labor and Capital? Evidence from } \\
\text { Vietnam }\end{array}$ \\
Nguyen Viet Cuong
\end{tabular}

http://www.ipag.fr/fr/accueil/la-recherche/publications-WP.html

IPAG Business School

184, Boulevard Saint-Germain

75006 Paris

France

IPAG working papers are circulated for discussion and comments only. They have not been peer-reviewed and may not be reproduced without permission of the authors. 


\title{
Do Minimum Wages Affect Firms' Labor and Capital? Evidence from Vietnam
}

\author{
Nguyen Viet Cuong ${ }^{1}$
}

\begin{abstract}
This study measures the effect of minimum wage increases on firm outcomes using fixed effects regression and panel data from Vietnam Enterprise Censuses during 2008-2010. It is found that minimum wages reduce firms' labor size, albeit at a small magnitude. A one percent increase in real minimum wages leads to a 0.1 percent reduction in the number of workers of firms. Firms are more likely to reduce male workers and those without social insurance. As a result, the proportion of female workers and workers with social insurance in firms increases due to minimum wages. Interestingly, under pressure of minimum wages, firms tend to increase assets, especially fixed assets, for labor substitution.
\end{abstract}

JEL Classification: J31; L25; P42

Keywords: minimum wages, firms, impact evaluation, panel data, Vietnam.

\footnotetext{
${ }^{1}$ National Economics University; and Mekong Development Research Institute, Hanoi, Vietnam; and Institut de Préparation à l'Administration et à la Gestion (IPAG Business School), Paris, France.

Email: c_nguyenviet@yahoo.com
} 


\section{Introduction}

Economists as well as policy makers have been long interested in the effect of minimum wages. A reason why the minimum wage is of interest is its possible negative effects. Positive effects of minimum wages are to prevent labor exploitation, to increase labor productiviy, increase income and consumption, and to reduce the number of people covered by social programs (Freeman, 1994; Dolado et al., 2000; Dowrick and Quiggin, 2003; Gunderson, 2005). However, minimum wages can lead to negative effects such as unemployment, production stagnation and increased prices.

The negative effect of minimum wages that concerns most economists and policy makers is employment reduction. In a competitive labor market, a rise in wage can lead to an increase in labor supply and a reduction in labor demand. There will be an excess in labor supply, and as a result, unemployment will be increased. Minimum wages can be harmful to a group of workers, especially the low-wage workers. However, in the "new minimum wage research", minimum wages are not always harmful to employment (Bazen, 2000; Neumark and Wascher, 2007). The effect of minimum wages is negligible if minimum wages are close to competitive wages or the elasticity of labor demand is less sensitive to wages (Dickens et al., 1995, and 1999).

Firms are the main employers in the economy. Since minimum wages can affect the labor cost and labor demand, minimum wages can also have an influence on firm performance. If higher production cost caused by minimum wages is passed to consumers, firms are not affected or affected eligibly by minimum wages. This case can happen for industries with very low price elasticity of demand. In a competitive market, the higher production cost cannot be passed fully to the consumers. In this case, the firms can respond to the minimum wages in two ways. The first way is to reduce the labor demand to keep the labor cost unchanged. In the second way, firms do not reduce the labor demand, and they are burdened with the higher labor cost due to increased minimum wages (Draca et al., 2011).

The effect of minimum wages on firm performance is unknown a priori. In the short-run, the sign and the magnitude of the minimum wage effect depend on firms' ability to pass the higher labor cost to consumers and firms' response to the labor demand. Empirical studies are ambiguous about the effect of minimum wages on employment and 
prices. Negative effects of minimum wages on employment are found in a large number of empirical studies (see review by Brown et al., 1982; Brown, 1999; Card and Krueger, 1995; Neumark and Wascher, 2007; Lemos, 2008), while no effects or even positive effects of minimum wage on employment are found in other studies such as Katz and Krueger (1992), Card and Krueger (1994, 2000), Montenegro and Pages (2004), Rama (2001). Likewise, a positive effect of minimum wages on prices is found in several studies, e.g., Card and Krueger (1995), Aaronson (2001), Macdonald and Aaronson (2000), but other studies such as Frye and Gordon (1981), Katz and Krueger (1992), Card and Krueger (1995) find very small or insignificant effects of minimum wages on prices. ${ }^{2}$

Although there are numerous empirical studies on the effect of minimum wages on employment as well as price in both developed and developing economies (Neumark and Wascher, 2007; Lemos, 2008), there are only a few studies on the effect of minimum wages on firms' business performance and the effect of minimum wages on firms found in these studies are not consistent. Draca et al. (2011) measures the effect of minimum wages on firm profitability in the United Kingdom using difference-in-differences method and find a negative effect of minimum wages on firm profitability. However, Nguyen (2009a) finds no effects of minimum wages on firm profits in Vietnam. Pacheco and Naiker (2007) do not find a significant effect on minimum wages on profits in New Zealand.

To my knowledge, there have been no studies on the effect of minimum wages on non-labor capital of firms. Labors and capital can be complementary and substitutionary. If labor and capital are perfectly substituted, firms can substitute physical capital for lowwage workers (Draca et al., 2011). As a result, capital can be increased due to minimum wages. In case in which labor and capital are perfectly complementary, if minimum wages decrease labor, capital can be also reduced. However, Bauducco and Janiak (2012) show that minimum wages can increase both labor and capital when labor and capital are perfectly complementary.

\footnotetext{
${ }^{2}$ For review of the effect of minimum wages in developing countries, see Cunningham (2007), Eyraud and Saget (2005), Kristensen and Cunningham (2006), Maloney and Mendez (2003) and World Bank (2006), Neumark and Wascher (2007), Lemos (2008).
} 
This study aims to examine the effect of minimum wages of firm outcomes including the number and structure of laborers, labor cost, and assets in Vietnam. There have been 12 adjustments of monthly minimum wages in Vietnam since 1994. Before 2008, there was only a common national minimum wage in Vietnam. Since 2008, there have been four levels of minimum wages applied for four different regions. Higher nominal minimum wages are applied in the better-off regions, while lower nominal minimum wages are applied in the worse-off regions. The increase in real minimum wages during 1994-2008 was rather low, at around 5 percent annually. This growth rate was lower than the GDP growth rate during the same period, and it is possible that minimum wages were lower than market wages. However, since 2008 the real minimum wage has been rising remarkably, with the annual growth rate of around 15 percent. During the current economic slowdown, minimum wage increases can have harmful effects on firms' performance.

In Vietnam, minimum wage increases always lead to debates about possible harmful impacts of minimum wages. There are some people favoring minimum wage increases (Duy, 2009; Can, 2009), while others worry about effects of minimum wages on labor cost and inflation (Thai, 2009; Minh, 2010). There are several quantitative studies on the impact of minimum wages in Vietnam. Nguyen (2011) measures the effect of minimum wages on monthly Consumer Price Index (CPI) during 1994-2008 and does not find a significant effect of minimum wage on CPI. Nguyen (2009b) uses household surveys to measure the effect of minimum wage adjustment in 2005 on employment and find a negative effect of minimum wages on formal employment. Nguyen (2009a) also investigates the effect of the minimum wage adjustment in 2005 but on firm profitability using enterprise surveys. He does not find an effect on the minimum wage adjustment on firms' profit.

Unlike Nguyen (2009a, 2009b) which examine the effect of the minimum wage increase in 2008, this study investigates the effect of the minimum wage increases on firms during the 2008-2010 period in Vietnam. Compared with Draca et al. (2011), Nguyen (2009a), and Pacheco and Naiker (2007), this study measures the effect of minimum wages on not only labor but also labor cost and assets of firms.

This paper is structured into six sections. The second section reviews the minimum wages in Vietnam. The third section presents the data sets and descriptive statistics of firms in Vietnam. The fourth and fifth sections present the estimation method and empirical results, respectively. Finally, the sixth section concludes. 


\section{Minimum wages in Vietnam}

In Vietnam, the Labor Law regulates that minimum wages are required to guanrantee the minimum living standard for a worker. Minimum wages are adjusted when there is inflation and improvement in living standards of people. There are several points of minimum wages in Vietnam that should be noted. Firstly, there is only monthly minimum wages in Vietnam. The government is considering the issue of hourly or daily minimum wages in the near future. Secondly, different minimum wages are applied for domestic employers and foreign employers. The minimum wages of workers (both Vietnamese and foreign workers) in the foreign sector are higher than those in the domesic sector. Thirdly, before 2008 there was a common minimum wage for the domestic sector. This minimum wage is also used to construct the wage scale for workers in public sector (including civil servants and workers in State-owned enterprises). The lowest wage is the minimum wage level, while higher wages are set equal to the minimum wage level multiplied by a coefficient. Since 2008 there have been different minimum wages for different regions. However, there is still a so-called 'a basic wage' for wage scale of the public sector. Figure 1 shows nominal and real minimum wages during 1994-2006, and the nominal and real 'basic wage' during 2008-2010.

Figure 1: Monthly minium wages for the domestic sector in Vietnam (thousand VND)

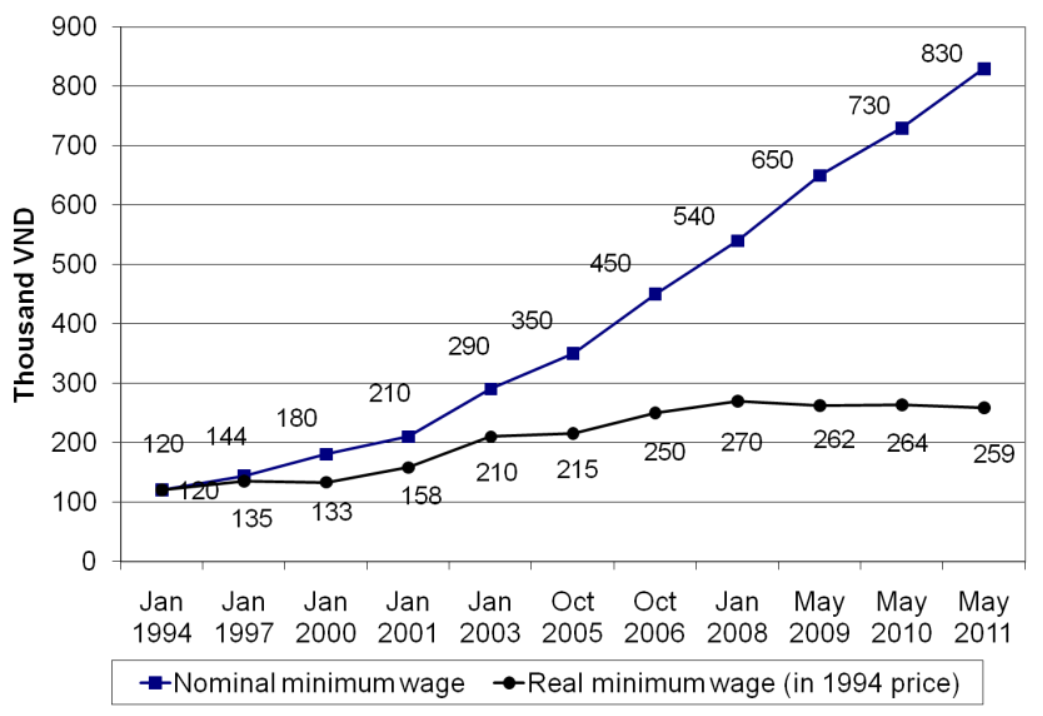

Source: Author's preparation based on the data on minimum wages 
Actual minimum wages are set independently of the basic wage. Table 1 presents the nominal minimum wages for different regions since $2008 .^{3}$ The nominal minimum wages increased at a higher rate than the inflation rate. Thus, real minimum wages increased slightly by around 5 percent over the period 2008-2011.

It should be noted that the minimum wage level for the period 2008-2011 have been planned by the government from 2008 (MOLISA, 2008). Since 2008, minimum wages have been constructed using a basic need approach (Tran et al., 2009). The basic needs include food and non-food consumption. The food consumption is required to ensure $2300 \mathrm{kcal} /$ day for an adult and $1600 \mathrm{kcal} /$ day for a child. Tran et al. (2009) estimate regional minimum wages which allow for food consumption of an adult and a child plus some sufficient non-food consumption. These minimum wages are estimated using the Vietnam Household Living Standard Survey in 2006, and they are constructed for the period 2008-2010 using the predicted CPI deflators.

Table 1: Regional nominal minimum wages (thousand VND)

\begin{tabular}{|c|c|c|c|c|c|c|c|c|}
\hline \multirow[t]{2}{*}{ Minimum wage regions } & \multicolumn{4}{|c|}{ Domestic sector } & \multicolumn{4}{|c|}{ Foreign sector } \\
\hline & 2008 & 2009 & 2010 & 2011 & 2008 & 2009 & 2010 & 2011 \\
\hline $\begin{array}{l}\text { Region 1: Urban districts } \\
\text { of Hanoi and Ho Chi } \\
\text { Minh city (region 1) }\end{array}$ & 620 & 800 & 980 & 2000 & 1000 & 1200 & 1340 & 2000 \\
\hline $\begin{array}{l}\text { Region 2: Several rural } \\
\text { areas of Hanoi and Ho } \\
\text { Chi Minh city, districts of } \\
\text { large cities }\end{array}$ & 580 & 740 & 880 & 1780 & 900 & 1080 & 1190 & 1780 \\
\hline $\begin{array}{l}\text { Region 3: other rural } \\
\text { areas of Hanoi, districts } \\
\text { of small cities, and others }\end{array}$ & 580 & 690 & 810 & 1550 & 900 & 950 & 1040 & 1550 \\
\hline Region 4: Other areas & 540 & 650 & 730 & 1400 & 800 & 920 & 1000 & 1400 \\
\hline $\begin{array}{l}\text { Note: In } 2008 \text {, there were } \\
\text { four minimum wage level } \\
\text { Source: Author's preparat }\end{array}$ & $\begin{array}{l}\text { ree } \mathrm{m} \\
\mathrm{r} \text { four } \\
\text { based }\end{array}$ & $\begin{array}{l}\text { um v } \\
\text { ions. } \\
\text { the da }\end{array}$ & level & r three & & & & \\
\hline
\end{tabular}

\section{Data set and firms in Vietnam}

\subsection{Enterprise census}

\footnotetext{
${ }^{3}$ For detailed definition of minimum wage regions, see Government of Vietnam (2009).
} 
The data used in this study are from the most recent Vietnam Enterprise Censuses in 2008, 2009 and 2010 (abbreviated as EC 2008, EC 2009 and EC 2010). These censuses were conducted by General Statistical Office of Vietnam. The censuses covered all registered enterprises throughout the country. The number of observations in EC 2008, EC 2009 and EC 2010 is 205689,233235 and 287896, respectively. It is interesting that these censuses set up panel data. The unbalanced panel data include 547733 observations, in which there are 155590 observations from EC 2008, 205833 observations from EC 2009 and 186310 observations from EC 2010. All the monetary variables are adjusted into the January 2008 price to eliminate the inflation effect.

The Enterprise Censuses collect rather detailed information on firms' business activities. Information includes type of firms, main business industries, the number of workers, male and female workers, workers with social insurance, labor cost, assets, turnover and profit of firms.

Table 2 shows the percentage of enterprises by geographic areas, ownership types, main business industry and labor size. The number of firms increased remarkably during 2008-2010. Most enterprises are located in urban areas, big cities, provinces in delta regions. Half of the enterprises lie in the two largest cities, Hanoi capital and Ho Chi Minh city. Other provinces and cities that have high concentration of firms, especially foreign invested firms are Hai Phong, Dong Nai and Binh Duong. By ownership type, the (private) limited companies account for the largest proportion, followed by private firms and joint-stock firms. The firms with foreign investment and State firms have much a much lower number. Most firms have small labor sizes. Around 60 percent of firms have less than 10 workers. Big firms with more than 300 workers account for around 2 percent.

Table 2: Distribution of firms by basic characteristics

\begin{tabular}{lccc}
\hline & 2008 & 2009 & 2010 \\
\hline Rural/Urban & & & \\
Rural & 25.26 & 25.73 & 24.49 \\
Urban & 74.74 & 74.27 & 75.51 \\
\hline Regions & & & \\
Northern Mountains & 5.62 & 5.38 & 5.02 \\
Red River Delta & 29.89 & 27.28 & 28.98 \\
Central Coast & 15.11 & 15.84 & 15.38 \\
Highland & 3.18 & 3.25 & 2.85 \\
South East & 35.75 & 37.91 & 38.67 \\
Mekong River Delta & 10.44 & 10.34 & 9.10 \\
\hline Provinces & & & \\
Ha Noi & 19.25 & 16.65 & 18.59
\end{tabular}




\begin{tabular}{|c|c|c|c|}
\hline & 2008 & 2009 & 2010 \\
\hline Hai Phong & 2.40 & 2.55 & 2.33 \\
\hline Binh Duong & 2.60 & 2.86 & 2.83 \\
\hline Dong Nai & 2.99 & 3.19 & 2.73 \\
\hline Ho Chi Minh city & 28.12 & 29.30 & 30.65 \\
\hline Other provinces & 44.64 & 45.44 & 42.87 \\
\hline \multicolumn{4}{|l|}{ Firm type } \\
\hline State & 1.58 & 1.48 & 1.20 \\
\hline Collective & 6.59 & 5.53 & 4.50 \\
\hline Private & 22.60 & 20.53 & 17.45 \\
\hline Limited company & 50.28 & 53.17 & 55.93 \\
\hline Joint-stock & 16.31 & 16.48 & 18.40 \\
\hline Foreign & 2.64 & 2.81 & 2.53 \\
\hline \multicolumn{4}{|l|}{ Business industry } \\
\hline Agriculture & 4.11 & 3.86 & 3.33 \\
\hline Food manufacturing and Processing & 3.11 & 2.86 & 2.44 \\
\hline Garment and textile & 2.72 & 2.63 & 2.51 \\
\hline Wood and papers & 2.27 & 2.21 & 1.93 \\
\hline Manufacture and mining & 13.42 & 13.04 & 11.73 \\
\hline Construction & 13.74 & 14.20 & 14.77 \\
\hline Trade & 39.26 & 38.71 & 39.14 \\
\hline Services & 21.37 & 22.48 & 24.14 \\
\hline \multicolumn{4}{|l|}{ Firm size } \\
\hline $1-5$ & 30.61 & 30.18 & 33.72 \\
\hline $6-10$ & 30.94 & 32.20 & 30.00 \\
\hline $11-30$ & 23.55 & 22.37 & 21.70 \\
\hline $31-100$ & 9.32 & 9.65 & 9.33 \\
\hline $101-300$ & 3.65 & 3.75 & 3.52 \\
\hline Above 300 & 1.93 & 1.85 & 1.73 \\
\hline All firms & $100 \%$ & $100 \%$ & $100 \%$ \\
\hline Source: Estimation from EC 2008, E & 2010. & & \\
\hline
\end{tabular}

\subsection{Firm characteristics}

Table 3 and 4 present the main characteristics of firms in the data set. The labor size of firms decreased from 36 laborers to 33 laborers during 2008-2010 (Table 3). One possible reason is that there were a large number of firms established in 2010. These newly established firms often have a small size. Firms in cities with industrial zones such as Dong Nai and Binh Duong tend to have larger labor sizes. State-owned firms, foreigninvested firms, and firms in textile, garment and process have a larger number of workers than other firms. 
There is a large variation in wages between different types of firms. Workers in firms in delta regions and large cities tend to have higher wages. Wages in State and foreign firms and firms in industrial and trade sectors are higher than private firms and firms in other sectors. ${ }^{4}$

Table 3: Labor and wages in firms

\begin{tabular}{|c|c|c|c|c|c|c|}
\hline & \multicolumn{3}{|c|}{ The number of workers } & \multicolumn{3}{|c|}{ Average wage (million VND/worker) } \\
\hline & 2008 & 2009 & 2010 & 2008 & 2009 & 2010 \\
\hline \multicolumn{7}{|l|}{ Rural/Urban } \\
\hline Rural & 41.4 & 40.4 & 39.8 & 1.38 & 1.66 & 1.92 \\
\hline Urban & 34.6 & 33.2 & 30.9 & 2.12 & 2.26 & 2.67 \\
\hline \multicolumn{7}{|l|}{ Regions } \\
\hline Northern Mountains & 39.7 & 40.7 & 42.3 & 1.35 & 1.63 & 1.83 \\
\hline Red River Delta & 38.6 & 40.5 & 34.9 & 2.01 & 2.22 & 2.90 \\
\hline Central Coast & 31.7 & 29.9 & 28.9 & 1.27 & 1.48 & 1.67 \\
\hline Highland & 34.5 & 31.5 & 33.3 & 1.58 & 1.82 & 1.97 \\
\hline South East & 38.6 & 34.9 & 33.3 & 2.48 & 2.54 & 2.85 \\
\hline Mekong River Delta & 27.1 & 27.5 & 28.5 & 1.21 & 1.49 & 1.56 \\
\hline \multicolumn{7}{|l|}{ Provinces } \\
\hline $\mathrm{Ha}$ Noi & 29.5 & 32.7 & 26.8 & 2.38 & 2.66 & 3.53 \\
\hline Hai Phong & 52.2 & 49.9 & 45.4 & 1.67 & 1.79 & 2.07 \\
\hline Binh Duong & 115.9 & 100.2 & 92.1 & 2.08 & 2.28 & 2.37 \\
\hline Dong Nai & 60.6 & 55.3 & 58.1 & 1.8 & 2.39 & 2.28 \\
\hline Ho Chi Minh city & 27.6 & 25.6 & 25.1 & 2.63 & 2.63 & 2.96 \\
\hline Other provinces & 37.5 & 35.6 & 35.4 & 1.3 & 1.55 & 1.74 \\
\hline \multicolumn{7}{|l|}{ Firm type } \\
\hline State & 397.4 & 370.5 & 361.2 & 2.82 & 3.31 & 3.70 \\
\hline Collective & 20.0 & 20.8 & 20.6 & 0.77 & 0.89 & 1.01 \\
\hline Private & 12.3 & 12.4 & 12.6 & 1.44 & 1.63 & 1.74 \\
\hline Limited company & 21.5 & 20.4 & 19.7 & 2.07 & 2.15 & 2.53 \\
\hline Joint-stock & 47.7 & 48.1 & 43.8 & 2.29 & 2.45 & 3.01 \\
\hline Foreign & 275.3 & 252.9 & 259.7 & 3.64 & 4.35 & 4.80 \\
\hline \multicolumn{7}{|l|}{ Business industry } \\
\hline Agriculture & 40.3 & 37.0 & 36.7 & 0.66 & 0.76 & 0.85 \\
\hline Food manufacturing and Processing & 79.0 & 79.7 & 81.9 & 1.35 & 1.58 & 1.70 \\
\hline Garment and textile & 230.2 & 213.9 & 207.8 & 1.63 & 1.67 & 1.92 \\
\hline Wood and papers & 45.1 & 43.0 & 42.1 & 1.34 & 1.55 & 1.64 \\
\hline Manufacture and mining & 68.2 & 69.0 & 69.1 & 1.66 & 1.96 & 2.17 \\
\hline Construction & 42.7 & 40.8 & 39.3 & 1.93 & 2.13 & 2.58 \\
\hline Trade & 12.0 & 12.0 & 11.6 & 1.95 & 2.12 & 2.60 \\
\hline Services & 24.0 & 23.7 & 22.2 & 2.47 & 2.55 & 2.82 \\
\hline \multicolumn{7}{|l|}{ Firm size } \\
\hline $1-5$ & 3.8 & 3.8 & 3.7 & 1.88 & 1.99 & 2.43 \\
\hline
\end{tabular}

\footnotetext{
${ }^{4}$ There is no data on wages for each worker in the data set. The average wage per workers is calculated by the total payment of firms for workers divided by the number of workers.
} 


\begin{tabular}{lcccccc}
\hline & \multicolumn{3}{c}{ The number of workers } & \multicolumn{3}{c}{ Average wage (million VND/worker) } \\
\cline { 2 - 7 } & 2008 & 2009 & 2010 & 2008 & 2009 & 2010 \\
\hline $6-10$ & 7.8 & 7.7 & 7.8 & 1.92 & 2.08 & 2.52 \\
$11-30$ & 17.8 & 17.9 & 17.9 & 1.9 & 2.08 & 2.42 \\
$31-100$ & 53.9 & 53.6 & 53.5 & 2.01 & 2.32 & 2.58 \\
$101-300$ & 171.0 & 169.7 & 169.2 & 2.17 & 2.53 & 2.68 \\
Above 300 & 892.7 & 859.2 & 845.2 & 2.31 & 2.64 & 2.86 \\
\hline All firms & 36.2 & 35.0 & 33.1 & 1.93 & 2.1 & 2.49 \\
\hline Note: The monetary variables are measured in the Jan 2008 price. \\
Source: Estimation from EC 2008, EC 2009 and EC 2010. \\
\hline
\end{tabular}

The proportion of workers with social insurance and female workers is just around 30 percent. These proportions are stable during 2008-2010. From the EC data set, we are not able to know the proportion of female workers having social insurance. In urban areas and large cities, the proportion of workers having social insurance is higher than rural areas and other cities. Interestingly, workers in Northern region are more likely to have social insurance.

Table 4: The proportion of workers with social insurance and female workers (\%)

\begin{tabular}{|c|c|c|c|c|c|c|}
\hline & \multicolumn{3}{|c|}{$\%$ workers with social insurance } & \multicolumn{3}{|c|}{$\%$ female workers } \\
\hline & 2008 & 2009 & 2010 & 2008 & 2009 & 2010 \\
\hline \multicolumn{7}{|l|}{ Rural/Urban } \\
\hline Rural & 31.99 & 31.28 & 32.50 & 31.66 & 32.56 & 32.64 \\
\hline Urban & 38.00 & 34.76 & 38.97 & 35.70 & 36.21 & 36.72 \\
\hline \multicolumn{7}{|l|}{ Regions } \\
\hline Northern Mountains & 41.50 & 42.30 & 43.88 & 29.71 & 31.45 & 32.79 \\
\hline Red River Delta & 32.30 & 34.28 & 34.42 & 35.12 & 36.18 & 36.56 \\
\hline Central Coast & 30.74 & 30.35 & 29.02 & 33.51 & 34.67 & 34.19 \\
\hline Highland & 26.15 & 26.98 & 27.98 & 34.55 & 33.88 & 33.11 \\
\hline South East & 44.39 & 36.91 & 44.43 & 36.38 & 36.77 & 37.52 \\
\hline Mekong River Delta & 19.16 & 19.84 & 22.40 & 32.11 & 30.64 & 30.27 \\
\hline \multicolumn{7}{|l|}{ Provinces } \\
\hline Ha Noi & 32.28 & 33.86 & 35.41 & 36.17 & 37.57 & 37.87 \\
\hline Hai Phong & 29.48 & 29.79 & 33.53 & 34.93 & 37.10 & 35.72 \\
\hline Binh Duong & 50.63 & 48.16 & 44.67 & 36.81 & 37.42 & 35.59 \\
\hline Dong Nai & 36.88 & 29.53 & 30.86 & 32.68 & 33.17 & 31.61 \\
\hline Ho Chi Minh city & 45.14 & 37.23 & 45.84 & 36.81 & 37.18 & 38.42 \\
\hline Other provinces & 29.45 & 29.94 & 29.95 & 32.67 & 33.05 & 33.07 \\
\hline \multicolumn{7}{|l|}{ Firm type } \\
\hline State & 89.28 & 89.87 & 90.28 & 32.64 & 32.49 & 32.58 \\
\hline Collective & 42.69 & 46.79 & 44.92 & 22.73 & 24.96 & 25.41 \\
\hline Private & 22.36 & 18.68 & 23.55 & 36.80 & 36.63 & 36.65 \\
\hline Limited company & 35.59 & 31.21 & 36.25 & 34.88 & 35.39 & 36.06 \\
\hline Joint-stock & 39.52 & 39.32 & 40.32 & 33.07 & 34.01 & 34.30 \\
\hline
\end{tabular}




\begin{tabular}{lcccccc}
\hline & \multicolumn{2}{c}{ \% workers with social insurance } & \multicolumn{3}{c}{ \% female workers } \\
\cline { 2 - 6 } & 2008 & 2009 & 2010 & 2008 & 2009 & 2010 \\
\hline Foreign & 81.74 & 81.81 & 81.90 & 48.82 & 48.95 & 49.42 \\
\hline Business industry & & & & & & \\
Agriculture & 46.09 & 49.64 & 45.69 & 20.47 & 21.32 & 21.78 \\
Food manufacturing and Processing & 39.97 & 38.41 & 39.88 & 39.38 & 39.18 & 40.14 \\
Garment and textile & 49.29 & 48.98 & 50.25 & 66.46 & 66.12 & 66.10 \\
Wood and papers & 37.78 & 37.05 & 38.86 & 34.81 & 35.89 & 35.56 \\
Manufacture and mining & 47.95 & 46.32 & 49.90 & 28.83 & 30.31 & 31.23 \\
Construction & 25.58 & 27.98 & 26.87 & 19.42 & 20.52 & 20.01 \\
Trade & 32.14 & 27.58 & 34.96 & 37.67 & 38.15 & 38.96 \\
Services & 42.82 & 38.66 & 40.43 & 39.75 & 39.96 & 40.04 \\
\hline Firm size & & & & & \\
1-5 & 27.16 & 22.25 & 31.64 & 38.64 & 39.73 & 39.28 \\
6-10 & 31.22 & 29.24 & 33.51 & 34.31 & 34.84 & 35.20 \\
11-30 & 44.71 & 43.21 & 39.81 & 30.73 & 31.07 & 31.71 \\
31-100 & 54.45 & 54.38 & 53.25 & 30.23 & 30.51 & 32.00 \\
101-300 & 64.38 & 62.78 & 61.24 & 35.76 & 35.06 & 35.82 \\
Above 300 & 72.43 & 74.25 & 72.65 & 46.91 & 46.74 & 46.21 \\
\hline All firms & 36.73 & 34.02 & 37.58 & 34.72 & 35.30 & 35.74 \\
\hline Source: Estimation from EC 2008, EC 2009 and EC 2010. & & & & \\
\hline
\end{tabular}

\section{Impact estimation strategy}

Impact evaluation of a policy or a program is always challenging. Measuring the effect of minimum wages is difficult for at least two reasons. Firstly, minimum wages are often a national program and there are no clean control groups who are not absolutely affected by minimum wages. Secondly, minimum wages are not randomly assigned, but based on CPI and other economic and political variables. The most popular method to measure the effect of minimum wages is difference-in-differences estimators (see review by Neumark and Wascher, 2007). Other methods with better identification strategies are instrumental variables and discontinuity regression. The instrumental variable estimator is traditional in impact evaluation, however, finding a valid instrumental variable for minimum wages is not easy. The discontinuity estimator has been applied recently (e.g., Dube et al., 2010) when there is a clear-cut selection of subjects exposed to minimum wages and those not exposed to minimum wages.

In this study, we use fixed-effects regression to measure the effect of minimum wages in Vietnam. More specifically, we assume an outcome of firms as the following function: 


$$
\ln \left(Y_{i k t}\right)=\beta_{0}+T_{t} \beta_{1}+X_{i k t} \beta_{2}+\ln \left(M W_{k}\right) \beta_{3}+X_{i k t} \ln \left(M W_{k}\right) \beta_{4}+v_{i j k}+u_{i j k t},
$$

where, $Y_{i k t}$ is a performance indicator of firm $i$ (for example labor size or turnover) in region $k$ (four regions) at the time $t . T_{t}$ is the dummy variable of year $t . X_{i k t}$ is a vector of firm characteristics. $M W_{k}$ is the minimum wage level in region $k . v_{i k}$ and $u_{i k t}$ are unobserved variables that are time-invariant and time-variant, respectively. This function is rather popular in studies of minimum wages (see Neumark and Wascher, 2007).

We use similar specifications as equation (1) to measure the effect of minimum wages on different outcomes of firms including labor size, labor cost and assets. In other words, we use regress different firm outcomes (dependent variables) on the same set of explanatory variables. Most dependent variables are in the logarithm form. Some dependent variables such as the ratio of female workers to total workers are not in the logarithm form.

It should be noted that we use the variable of logarithm of real minimum wages. We do not use the Kaitz index or any ratio of minimum wages to average wages. Since the average wages can be also affected by minimum wages, and this makes it difficult to interpret the effect of minimum wages on firm outcomes. However, we still control for the regional average wage of the previous years. The minimum wages vary across four regions and foreign and domestic sectors. For each year, there are eight levels of minimum wages. This definition of minimum wages is different from those of Nguyen (2009b) and Draca (2011). Nguyen (2009b) measures the effect of the minimum wage increase in 2005. In 2005, there was only a common minimum wage in Vietnam, and there is no information on the number of workers below the minimum wage in firms in data sets. Thus, in Nguyen (2009b), firms that have the average wage below the minimum wage are defined as the treatment group, while those that have the average wage above the minimum wage are defined as the control group. A problem is that the control groups can also include firms that have a number of workers below the minimum wage.

The explanatory variables $X$ include exogenous variables that should not be affected by minimum wages (Heckman et al., 1999; Angrist and Pischke, 2008). Minimum wages are adjusted mainly based on the CPI, the living cost of regions, and the average wages of regions. These variables can affect firm activities and should be controlled for. Thus the explanatory variables include regional CPI, the provincial gross output of agriculture, service and industry per capita, the labor force of provinces (the total 
number of people above 14 years old), and the average wages of regions. ${ }^{5}$ The agricultural, industrial and service output per capita are proxies of living standards. Explanatory variables are in the logarithm form. We use lagged variables (the previous year variables) so that they are not affected by minimum wages of the current year.

The difficulty in measuring minimum wages is the endogeneity of minimum wages in outcome equations. Unobserved variables can affect both minimum wages and firm outcomes. In this study, we are not able to find a convincing instrument for minimum wages in Vietnam. Discontinuity estimators cannot be applied since minimum wages are adjusted simultaneously throughout the country. Thus in this study, we use fixed-effects regression to estimate the effect of minimum wages. Fixed-effects regression eliminates the time-invariant unobserved variables $v_{i k}$. It is expected that the bias caused by the endogeneity of minimum wages will be negligible after elimination of the time-invariant unobserved variables and control of main observed variables that affect minimum wages (CPI and regional outputs). In addition, the minimum wages have been set up by the government of Vietnam since 2008 (MOLISA, 2008), and this fact can cause more exogenous variables in the minimum wages in the equation of firm outcomes.

\section{Estimation results}

\subsection{The impact of minimum wages: no interactions}

This section presents the estimation results of minimum wage effects on firm outcomes. In this section, we do not include interactions between the minimum wage variable with other firm characteristics in regressions. In the next section, we will include interactions between the minimum wage variable with other firm characteristics to examine whether the effect of minimum wages differs for different types of firms.

Tables 5 and 6 present the fixed-effects regressions of firm performances on minimum wages and other explanatory variables. Several dependent variables are in a

\footnotetext{
${ }^{5}$ There are 4 regions of minimum wages, but there are 8 geographical regions in Vietnam. In regressions , we control for the CPI of 8 regions.
} 
logarithm form. ${ }^{6}$ Variables that are fixed over time such as regions and firm types are removed in fixed-effects regressions.

A problem in panel data model is serial correlation of error terms. Although the serial correlation does not affect the biasness of estimators, it can affect the validity of the standard error of the estimators. Using a serial correlation test of Wooldridge (2010), the hypothesis on no serial correlation in our regressions is strongly rejected. Thus, we use the fixed-effect regressions with Driscoll-Kraay standard errors that are robust to serial correlation and heteroskedastic (Driscoll and Kraay, 1998; Hoechle, 2007).

Table 5 shows that minimum wages have a small and negative effect on the labor size of firms. A one-percent increase in real minimum wages reduces the number of workers by 0.1 percent. It implies that if the average labor size of firms is around 33, a one-percent increase in real minimum wages can reduce the average labor size by approximately 0.033 worker. This effect is small, compared with the effect found in empirical studies in the United States in which a one-percent increase in minimum wages lead to a 0.1 to 0.3 percent reduction in employment (Brown et al., 1982; Brown, 1999; Card and Krueger, 1995; Neumark and Wascher, 2007).

Interestingly, minimum wages have a small effect on labor composition of firms. A one-percent increase in real minimum wages increase the proportion of female workers and workers with social insurance by around 0.06 and 0.21 percentage points, respectively. The findings imply that firms tend to reduce the number of workers without social insurance instead of workers with social insurance. Workers without social insurance are more likely to have low skills and short-term labor contracts. Firing workers who have social insurance is often more complicated in terms of legal labor regulations. Male workers are more likely to be reduced due to minimum wages. This finding is difficult to interpret since male workers might be more likely to have higher skills. Further studies are needed to understand the channel through which minimum wages can affect different type of workers. ${ }^{7}$

\footnotetext{
${ }^{6}$ For double $\log$ functions, the effect of minimum wages is measured by coefficient of $\ln \left(M W_{k}\right)$, and the estimated coefficient is interpreted as the elasticity of dependent variables with respect to minimum wage. When dependent variables are in a linear form (not in the logarithm form): as the minimum wage level changes by 1 percent, the value of the dependent variables changes by the coefficient of $\ln \left(M W_{k}\right)$ divided by 100 (see Wooldridge, 2011).

${ }^{7}$ In the data sets, there are no data on wages on workers by skills or education.
} 
The average wage per worker increases due to minimum wages. However, the increase is very small. A one-percent increase in minimum wages leads to 0.076 percent increase in the average wages. This might be because the proportion of workers who receive wages below the minimum wages is small, and the minimum wages only have a positive effect on wages of these low-wage workers. Since minimum wages have a small effect on labor size and wages per laborer, the effect of the minimum wages on total labor cost of firms is very small and not statistically significant.

Table 5: Regressions of laborers and wages

\begin{tabular}{|c|c|c|c|c|c|}
\hline \multirow[b]{2}{*}{ Explanatory variables } & \multicolumn{5}{|c|}{ Dependent variables } \\
\hline & $\begin{array}{l}\text { Log of the } \\
\text { number of } \\
\text { workers }\end{array}$ & $\begin{array}{l}\text { Proportion of } \\
\text { female } \\
\text { workers }\end{array}$ & $\begin{array}{l}\text { Proportion of } \\
\text { workers with } \\
\text { social } \\
\text { insurance }\end{array}$ & $\begin{array}{l}\text { Log of wage } \\
\text { per worker }\end{array}$ & $\begin{array}{l}\text { Log of total } \\
\text { wage cost }\end{array}$ \\
\hline \multirow{2}{*}{ Log of minimum wage } & $-0.102^{* *}$ & $0.059^{* * *}$ & $0.218^{* * *}$ & $0.076^{* *}$ & -0.001 \\
\hline & $(0.044)$ & $(0.002)$ & $(0.042)$ & $(0.023)$ & $(0.074)$ \\
\hline \multirow{2}{*}{ Year 2009} & $-0.012^{\star *}$ & $0.009^{* * *}$ & $0.006^{* * *}$ & $0.215^{\star * *}$ & $0.203^{* * *}$ \\
\hline & $(0.006)$ & $(0.003)$ & $(0.001)$ & $(0.019)$ & $(0.023)$ \\
\hline \multirow{2}{*}{ Year 2010} & $0.029^{* * *}$ & $0.014^{* * *}$ & $0.053^{* * *}$ & $0.334^{* * *}$ & $0.366^{\star * *}$ \\
\hline & $(0.009)$ & $(0.004)$ & $(0.007)$ & $(0.023)$ & $(0.029)$ \\
\hline \multirow{2}{*}{ Log of regional CPI in previous year } & $0.246^{* * *}$ & $0.026^{* * *}$ & 0.024 & $-0.121^{\star * *}$ & $0.135^{\star *}$ \\
\hline & $(0.046)$ & $(0.005)$ & $(0.040)$ & $(0.023)$ & $(0.064)$ \\
\hline \multirow{2}{*}{$\begin{array}{l}\text { Log of lagged labor force of } \\
\text { provinces }\end{array}$} & $-0.071^{* * *}$ & -0.024 & $-0.070^{\star * *}$ & $-0.420^{\star * *}$ & $-0.519^{\star \star *}$ \\
\hline & $(0.011)$ & $(0.015)$ & $(0.005)$ & $(0.061)$ & $(0.060)$ \\
\hline \multirow{2}{*}{$\begin{array}{l}\text { Log of lagged gross output of } \\
\text { agriculture per capita of provinces }\end{array}$} & $0.336^{* * *}$ & $-0.033^{\star *}$ & $0.227^{\star \star}$ & $0.185^{\star *}$ & $0.496^{\star * *}$ \\
\hline & $(0.040)$ & $(0.013)$ & $(0.088)$ & $(0.074)$ & $(0.120)$ \\
\hline \multirow{2}{*}{$\begin{array}{l}\text { Log of lagged gross output of } \\
\text { industry per capita of provinces }\end{array}$} & 0.003 & $-0.007^{\star *}$ & -0.006 & $0.134^{\star * *}$ & $0.136^{\star *}$ \\
\hline & $(0.015)$ & $(0.003)$ & $(0.013)$ & $(0.041)$ & $(0.060)$ \\
\hline \multirow{2}{*}{$\begin{array}{l}\text { Log of lagged gross output of service } \\
\text { per capita of provinces }\end{array}$} & 0.014 & $0.005^{\star}$ & $0.015^{\star * \star}$ & $0.019^{* * *}$ & 0.035 \\
\hline & $(0.034)$ & $(0.003)$ & $(0.005)$ & $(0.002)$ & $(0.035)$ \\
\hline \multirow{2}{*}{$\begin{array}{l}\text { Log of lagged regional average } \\
\text { wages }\end{array}$} & $0.059^{*}$ & -0.017 & $-0.236^{\star * \star}$ & $-0.419^{* * *}$ & $-0.335^{\star \star}$ \\
\hline & $(0.036)$ & $(0.011)$ & $(0.021)$ & $(0.122)$ & $(0.150)$ \\
\hline \multirow{2}{*}{ Constant } & $1.856^{\star \star \star}$ & 0.175 & $1.603^{* * *}$ & $16.752^{\star \star \star}$ & $18.383^{\star \star *}$ \\
\hline & $(0.171)$ & $(0.199)$ & $(0.180)$ & $(0.769)$ & $(0.803)$ \\
\hline Observations & 547,733 & 547,733 & 547,733 & 547,733 & 547,733 \\
\hline Within R-squared & 0.002 & 0.004 & 0.027 & 0.079 & 0.057 \\
\hline The number of firms & 205,834 & 205,834 & 205,834 & 205,834 & 205,834 \\
\hline \multicolumn{6}{|c|}{$\begin{array}{l}\text { Note: All monetary variables are measured in the January } 2008 \text { price. } \\
{ }^{* * *} p<0.01,{ }^{* *} p<0.05,{ }^{*} p<0.1 . \\
\text { Robust Driscoll-Kraay standard errors in parentheses. } \\
\text { Source: Estimation from EC } 2008, E C 2009 \text { and EC } 2010 .\end{array}$} \\
\hline
\end{tabular}

Table 6 presents the regressions of firms' assets or non-labor capitals. Interestingly, minimum wages lead to an increase in firm assets and the ratio of fixed 
assets to total assets. ${ }^{8}$ More specifically, a one-percent increase in minimum wages leads to a 0.75 percent increase in total assets and a 0.86 percent increase in fixed assets. The proportion of fixed assets to total assets rises by 0.176 percentage points as the minimum wages increase by one percent. Possibly, firms tend to increase assets to substitute labor to mitigate the effect of minimum wages on labor cost.

Table 6: Regressions of assets

\begin{tabular}{|c|c|c|c|c|c|}
\hline \multirow[b]{2}{*}{ Explanatory variables } & \multicolumn{5}{|c|}{ Dependent variables } \\
\hline & Log of asset & $\begin{array}{l}\text { Log of asset } \\
\text { per worker }\end{array}$ & $\begin{array}{l}\text { Log of fixed } \\
\text { asset }\end{array}$ & $\begin{array}{l}\text { Log of fixed } \\
\text { asset per } \\
\text { worker }\end{array}$ & $\begin{array}{l}\text { Proportion of } \\
\text { fixed asset to } \\
\text { total asset }\end{array}$ \\
\hline \multirow{2}{*}{ Log of minimum wage } & $0.752^{* * *}$ & $0.858^{* * *}$ & $1.205^{\star * *}$ & $1.275^{\star \star \star}$ & $0.176^{\star * *}$ \\
\hline & $(0.058)$ & $(0.101)$ & $(0.080)$ & $(0.122)$ & $(0.010)$ \\
\hline \multirow{2}{*}{ Year 2009} & $0.060^{* * *}$ & $0.072^{* \star *}$ & $0.042^{* *}$ & $0.057^{* *}$ & -0.002 \\
\hline & $(0.007)$ & $(0.012)$ & $(0.022)$ & $(0.021)$ & $(0.004)$ \\
\hline \multirow{2}{*}{ Year 2010} & $0.240^{\star * *}$ & $0.209^{* * *}$ & $0.262^{* * *}$ & $0.231^{* * *}$ & -0.015 \\
\hline & $(0.021)$ & $(0.014)$ & $(0.009)$ & $(0.008)$ & $(0.010)$ \\
\hline \multirow{2}{*}{ Log of regional CPI in previous year } & $0.316^{\star * *}$ & $0.071^{* *}$ & $0.803^{* *}$ & 0.517 & $0.077^{* *}$ \\
\hline & $(0.080)$ & $(0.034)$ & $(0.287)$ & $(0.324)$ & $(0.034)$ \\
\hline \multirow{2}{*}{$\begin{array}{l}\text { Log of lagged labor force of } \\
\text { provinces }\end{array}$} & 0.038 & 0.106 & 0.124 & $0.189^{* *}$ & $-0.018^{*}$ \\
\hline & $(0.138)$ & $(0.134)$ & $(0.093)$ & $(0.093)$ & $(0.010)$ \\
\hline \multirow{2}{*}{$\begin{array}{l}\text { Log of lagged gross output of } \\
\text { agriculture per capita of provinces }\end{array}$} & $0.591^{\star \star \star}$ & $0.253^{\star *}$ & $0.461^{* *}$ & 0.121 & $-0.030^{\star}$ \\
\hline & $(0.154)$ & $(0.127)$ & $(0.169)$ & $(0.139)$ & $(0.017)$ \\
\hline \multirow{2}{*}{$\begin{array}{l}\text { Log of lagged gross output of } \\
\text { industry per capita of provinces }\end{array}$} & $-0.081^{\star \star \star}$ & $-0.084^{\star \star \star}$ & $-0.191^{\star \star \star}$ & $-0.187^{\star \star \star}$ & $-0.031^{\star \star \star}$ \\
\hline & $(0.016)$ & $(0.025)$ & $(0.020)$ & $(0.030)$ & $(0.003)$ \\
\hline \multirow{2}{*}{$\begin{array}{l}\text { Log of lagged gross output of service } \\
\text { per capita of provinces }\end{array}$} & -0.027 & $-0.042^{*}$ & -0.083 & -0.096 & $-0.023^{* * *}$ \\
\hline & $(0.054)$ & $(0.027)$ & $(0.096)$ & $(0.069)$ & $(0.006)$ \\
\hline \multirow{2}{*}{$\begin{array}{l}\text { Log of lagged regional average } \\
\text { wages }\end{array}$} & $0.255^{\star \star \star}$ & $0.197^{* * *}$ & $-0.067^{\star \star}$ & $-0.138^{* * *}$ & $-0.076^{\star *}$ \\
\hline & $(0.036)$ & $(0.012)$ & $(0.011)$ & $(0.030)$ & $(0.034)$ \\
\hline \multirow{2}{*}{ Constant } & $5.762^{\star \star \star}$ & $3.868^{* * *}$ & 1.655 & 0.290 & -0.250 \\
\hline & $(0.409)$ & $(0.362)$ & $(1.559)$ & $(1.809)$ & $(0.143)$ \\
\hline Observations & 547,733 & 547,733 & 547,733 & 547,733 & 547,733 \\
\hline Within R-squared & 0.076 & 0.067 & 0.041 & 0.035 & 0.004 \\
\hline The number of firms & 205,834 & 205,834 & 205,834 & 205,834 & 205,834 \\
\hline \multicolumn{6}{|c|}{$\begin{array}{l}\text { Note: All monetary variables are measured in the January } 2008 \text { price. } \\
{ }^{* * *} p<0.01,{ }^{* *} p<0.05,{ }^{*} p<0.1 . \\
\text { Robust Driscoll-Kraay standard errors in parentheses. } \\
\text { Source: Estimation from EC } 2008, E C 2009 \text { and EC } 2010 .\end{array}$} \\
\hline
\end{tabular}

\subsection{The impact of minimum wages: with interactions}

\footnotetext{
${ }^{8}$ Fixed assets are non-current and physical assets such as plant and equipments.
} 
To examine the effect of minimum wages for different types of firm, we include interactions between the minimum wage variable and characteristics variables of firms. Table 7 and Table 8 present only the estimates of the minimum wage variable and these interaction terms. The full regressions are reported in Tables in Appendix.

It shows that the minimum wage effect on firm outcomes differs between urban and rural areas and regions. The minimum wage effect on wages per worker is higher in rural areas. Minimum wages help rural workers increase their wages.

Table 7: Regressions with interactions between minimum wages and demographic variables

\begin{tabular}{|c|c|c|c|c|c|c|}
\hline \multirow[b]{2}{*}{ Explanatory variables } & \multicolumn{6}{|c|}{ Dependent variables } \\
\hline & $\begin{array}{l}\text { Log of the } \\
\text { number of } \\
\text { workers }\end{array}$ & $\begin{array}{l}\text { Proportion } \\
\text { of female } \\
\text { workers }\end{array}$ & $\begin{array}{l}\text { Proportion } \\
\text { of workers } \\
\text { with social } \\
\text { insurance }\end{array}$ & $\begin{array}{c}\text { Log of } \\
\text { monthly } \\
\text { wages per } \\
\text { worker }\end{array}$ & $\begin{array}{l}\text { Log of total } \\
\text { asset }\end{array}$ & $\begin{array}{l}\text { Proportion } \\
\text { of fixed } \\
\text { asset to } \\
\text { total asset }\end{array}$ \\
\hline \multicolumn{7}{|c|}{ Model with interaction between minimum wages and urban } \\
\hline Log of minimum wages & $\begin{array}{l}-0.153^{*} \\
(0.080)\end{array}$ & $\begin{array}{l}0.046^{\star * *} \\
(0.004)\end{array}$ & $\begin{array}{c}0.268^{* * *} \\
(0.036)\end{array}$ & $\begin{array}{c}0.314^{* * *} \\
(0.042)\end{array}$ & $\begin{array}{l}0.952^{* * *} \\
(0.069)\end{array}$ & $\begin{array}{l}0.095^{\star \star *} \\
(0.013)\end{array}$ \\
\hline $\begin{array}{l}\text { Log of minimum wages * } \\
\text { Urban }\end{array}$ & $\begin{array}{c}0.046 \\
(0.031)\end{array}$ & $\begin{array}{l}0.012^{\star * *} \\
(0.002)\end{array}$ & $\begin{array}{c}-0.045^{\star * *} \\
(0.008)\end{array}$ & $\begin{array}{c}-0.217^{* * *} \\
(0.021)\end{array}$ & $\begin{array}{l}-0.183^{* *} \\
(0.073)\end{array}$ & $\begin{array}{l}0.074^{* * *} \\
(0.004)\end{array}$ \\
\hline \multicolumn{7}{|c|}{ Model with interaction between minimum wages and regions } \\
\hline Log of minimum wages & $\begin{array}{l}0.212^{\star *} \\
(0.079)\end{array}$ & $\begin{array}{l}0.101^{\star *} \\
(0.022)\end{array}$ & $\begin{array}{l}0.249^{\star \star} \\
(0.090)\end{array}$ & $\begin{array}{l}0.705^{\star \star} \\
(0.145)\end{array}$ & $\begin{array}{l}0.472^{\star *} \\
(0.181)\end{array}$ & $\begin{array}{l}-0.000 \\
(0.021)\end{array}$ \\
\hline $\begin{array}{l}\text { Log of minimum wages * } \\
\text { Northern Mountain }\end{array}$ & Omitted & & & & & \\
\hline $\begin{array}{l}\text { Log of minimum wages * } \\
\text { Red River Delta }\end{array}$ & $\begin{array}{l}-0.314^{\star * *} \\
(0.027)\end{array}$ & $\begin{array}{l}-0.038 \\
(0.038)\end{array}$ & $\begin{array}{c}0.009 \\
(0.023)\end{array}$ & $\begin{array}{l}-0.290^{\star *} \\
(0.147)\end{array}$ & $\begin{array}{c}0.319 \\
(0.225)\end{array}$ & $\begin{array}{l}0.071^{\star * \star} \\
(0.010)\end{array}$ \\
\hline $\begin{array}{l}\text { Log of minimum wages * } \\
\text { Central Coast }\end{array}$ & $\begin{array}{l}-0.039 \\
(0.031)\end{array}$ & $\begin{array}{l}-0.078^{\star *} \\
(0.033)\end{array}$ & $\begin{array}{l}0.076^{* * *} \\
(0.008)\end{array}$ & $\begin{array}{c}-0.376^{* * *} \\
(0.056)\end{array}$ & $\begin{array}{c}0.063 \\
(0.107)\end{array}$ & $\begin{array}{l}0.179^{\star * *} \\
(0.029)\end{array}$ \\
\hline $\begin{array}{l}\text { Log of minimum wages * } \\
\text { Highlands }\end{array}$ & $\begin{array}{l}-0.100 \\
(0.087)\end{array}$ & $\begin{array}{c}-0.136^{* * *} \\
(0.017)\end{array}$ & $\begin{array}{l}-0.012^{*} \\
(0.070)\end{array}$ & $\begin{array}{c}-0.853^{\star * *} \\
(0.103)\end{array}$ & $\begin{array}{l}0.957^{\star \star \star} \\
(0.043)\end{array}$ & $\begin{array}{l}-0.003 \\
(0.090)\end{array}$ \\
\hline $\begin{array}{l}\text { Log of minimum wages * } \\
\text { South East }\end{array}$ & $\begin{array}{c}-0.346^{* * *} \\
(0.081)\end{array}$ & $\begin{array}{l}-0.041^{* *} \\
(0.020)\end{array}$ & $\begin{array}{l}-0.088 \\
(0.141)\end{array}$ & $\begin{array}{c}-1.005^{\star \star *} \\
(0.114)\end{array}$ & $\begin{array}{l}0.268^{\star * *} \\
(0.081)\end{array}$ & $\begin{array}{l}0.274^{\star * *} \\
(0.024)\end{array}$ \\
\hline $\begin{array}{l}\text { Log of minimum wages * } \\
\text { Mekong River Delta }\end{array}$ & $\begin{array}{c}-0.147^{* * *} \\
(0.020)\end{array}$ & $\begin{array}{c}-0.185^{\star * *} \\
(0.009)\end{array}$ & $\begin{array}{c}0.019 \\
(0.020)\end{array}$ & $\begin{array}{l}-0.434^{* *} \\
(0.171) \\
\end{array}$ & $\begin{array}{r}0.118 \\
(0.151) \\
\end{array}$ & $\begin{array}{l}0.112^{\star *} \\
(0.052)\end{array}$ \\
\hline \multicolumn{7}{|c|}{ Model with interaction between minimum wages and provinces } \\
\hline Log of minimum wages & $\begin{array}{l}0.219^{\star \star \star} \\
(0.071)\end{array}$ & $\begin{array}{l}-0.003 \\
(0.009)\end{array}$ & $\begin{array}{l}0.307^{\star *} \\
(0.049)\end{array}$ & $\begin{array}{l}0.372^{* * *} \\
(0.090)\end{array}$ & $\begin{array}{l}0.648^{\star \star *} \\
(0.147)\end{array}$ & $\begin{array}{l}0.094^{* * *} \\
(0.012)\end{array}$ \\
\hline $\begin{array}{l}\text { Log of minimum wages * } \\
\text { Hanoi }\end{array}$ & $\begin{array}{c}-0.288^{* * *} \\
(0.010)\end{array}$ & $\begin{array}{l}0.073^{* *} \\
(0.026)\end{array}$ & $\begin{array}{l}-0.071 \\
(0.082)\end{array}$ & $\begin{array}{c}0.091 \\
(0.082)\end{array}$ & $\begin{array}{c}0.141 \\
(0.290)\end{array}$ & $\begin{array}{c}0.009 \\
(0.013)\end{array}$ \\
\hline $\begin{array}{l}\text { Log of minimum wages * Hai } \\
\text { Phong }\end{array}$ & $\begin{array}{l}-0.345^{* * *} \\
(0.037)\end{array}$ & $\begin{array}{c}0.038 \\
(0.037)\end{array}$ & $\begin{array}{l}0.124^{\star * *} \\
(0.039)\end{array}$ & $\begin{array}{l}-0.337 \\
(0.165)\end{array}$ & $\begin{array}{l}0.409^{\star *} \\
(0.185)\end{array}$ & $\begin{array}{l}-0.141^{* * *} \\
(0.027)\end{array}$ \\
\hline $\begin{array}{l}\text { Log of minimum wages * } \\
\text { Binh Duong }\end{array}$ & $\begin{array}{l}-0.761^{* * *} \\
(0.081)\end{array}$ & $\begin{array}{l}-0.080^{\star *} \\
(0.038)\end{array}$ & $\begin{array}{l}0.143^{* *} \\
(0.049)\end{array}$ & $\begin{array}{l}-0.022 \\
(0.122)\end{array}$ & $\begin{array}{l}-0.239 \\
(0.370)\end{array}$ & $\begin{array}{c}0.020 \\
(0.070)\end{array}$ \\
\hline $\begin{array}{l}\text { Log of minimum wages * } \\
\text { Dong Nai }\end{array}$ & $\begin{array}{l}-0.171 \\
(0.117)\end{array}$ & $\begin{array}{l}-0.074^{*} \\
(0.042)\end{array}$ & $\begin{array}{c}-0.401^{* * *} \\
(0.094)\end{array}$ & $\begin{array}{l}-0.104 \\
(0.315)\end{array}$ & $\begin{array}{l}-0.297^{\star *} \\
(0.104)\end{array}$ & $\begin{array}{l}0.143^{\star * *} \\
(0.009)\end{array}$ \\
\hline
\end{tabular}




\begin{tabular}{|c|c|c|c|c|c|c|}
\hline \multirow[b]{2}{*}{ Explanatory variables } & \multicolumn{6}{|c|}{ Dependent variables } \\
\hline & $\begin{array}{l}\text { Log of the } \\
\text { number of } \\
\text { workers }\end{array}$ & $\begin{array}{l}\text { Proportion } \\
\text { of female } \\
\text { workers }\end{array}$ & $\begin{array}{l}\text { Proportion } \\
\text { of workers } \\
\text { with social } \\
\text { insurance }\end{array}$ & $\begin{array}{l}\text { Log of } \\
\text { monthly } \\
\text { wages per } \\
\text { worker }\end{array}$ & $\begin{array}{l}\text { Log of total } \\
\text { asset }\end{array}$ & $\begin{array}{l}\text { Proportion } \\
\text { of fixed } \\
\text { asset to } \\
\text { total asset }\end{array}$ \\
\hline \multirow{2}{*}{$\begin{array}{l}\text { Log of minimum wages * Ho } \\
\text { Chi Minh city }\end{array}$} & $-0.355^{\star \star \star}$ & $0.066^{\star *}$ & -0.124 & $-0.473^{\star \star \star}$ & $0.054^{\star *}$ & $0.185^{\star \star \star}$ \\
\hline & $(0.053)$ & $(0.010)$ & $(0.098)$ & $(0.080)$ & $(0.027)$ & $(0.008)$ \\
\hline $\begin{array}{l}\text { Log of minimum wages * } \\
\text { Other provinces }\end{array}$ & Omitted & & & & & \\
\hline \multicolumn{7}{|c|}{$\begin{array}{l}\text { Note: All monetary variables are measured in the January } 2008 \text { price. } \\
{ }^{* * *} p<0.01,{ }^{* *} p<0.05,{ }^{*} p<0.1 . \\
\text { Standard errors in parentheses. } \\
\text { Source: Estimation from EC } 2008, E C 2009 \text { and EC } 2010 .\end{array}$} \\
\hline
\end{tabular}

The effect of minimum wages on labor size of firms tends to be higher in large cities and delta regions than mountain and highland regions and other provinces.

The minimum wage effect on firm outcomes varies across firms of different types. Minimum wages have no effect on labor demand of foreign-invested firms. State firms, private firms and limited companies are those most affected by minimum wages on the labor sizes. By industry, firms in construction, trade and service sectors are less likely to be affected by minimum wages.

Table 8 also examines whether the effect of minimum wages differs for firms of different labor sizes and firms of different asset sizes by including interactions between the minimum wage variables and the labor size in 2008 and the assets in 2008. We use the variables 2008 since they are not affected by minimum wage during 2008-2010. It shows that the minimum wage effect on the number of laborers is higher for firms with a large labor size than those with a small labor size.

Table 8: Regressions with interactions between minimum wages and characteristics variables of firms

\begin{tabular}{|c|c|c|c|c|c|c|}
\hline \multirow[b]{2}{*}{ Explanatory variables } & \multicolumn{6}{|c|}{ Dependent variables } \\
\hline & $\begin{array}{c}\text { Log of the } \\
\text { number of } \\
\text { workers }\end{array}$ & $\begin{array}{c}\text { Proportion } \\
\text { of female } \\
\text { workers }\end{array}$ & $\begin{array}{l}\text { Proportion } \\
\text { of workers } \\
\text { with social } \\
\text { insurance }\end{array}$ & $\begin{array}{c}\text { Log of } \\
\text { monthly } \\
\text { wages per } \\
\text { worker }\end{array}$ & $\begin{array}{l}\text { Log of total } \\
\text { asset }\end{array}$ & $\begin{array}{l}\text { Proportion } \\
\text { of fixed } \\
\text { asset to } \\
\text { total asset }\end{array}$ \\
\hline \multicolumn{7}{|c|}{ Model with interaction between minimum wages and type of firms } \\
\hline Log of minimum wages & $\begin{array}{c}-0.913^{\star * *} \\
(0.089)\end{array}$ & $\begin{array}{c}0.052^{\star * *} \\
(0.004)\end{array}$ & $\begin{array}{c}0.120 \\
(0.094)\end{array}$ & $\begin{array}{l}-0.024 \\
(0.156)\end{array}$ & $\begin{array}{c}-1.078^{\star \star *} \\
(0.175)\end{array}$ & $\begin{array}{c}0.000 \\
(0.063)\end{array}$ \\
\hline $\begin{array}{l}\text { Log of minimum wages * } \\
\text { State firms }\end{array}$ & $\begin{array}{c}0.163^{* * *} \\
(0.055)\end{array}$ & $\begin{array}{c}-0.060^{* *} \\
(0.009)\end{array}$ & $\begin{array}{l}-0.023 \\
(0.044)\end{array}$ & $\begin{array}{c}-0.123^{\star *} \\
(0.051)\end{array}$ & $\begin{array}{c}-0.100^{* *} \\
(0.043)\end{array}$ & $\begin{array}{c}0.163^{* * *} \\
(0.054)\end{array}$ \\
\hline $\begin{array}{l}\text { Log of minimum wages * } \\
\text { Collectives }\end{array}$ & Omitted & & & & & \\
\hline $\begin{array}{l}\text { Log of minimum wages * } \\
\text { Private firms }\end{array}$ & $\begin{array}{c}0.456^{\star * *} \\
(0.122)\end{array}$ & $\begin{array}{c}-0.037^{* * *} \\
(0.010)\end{array}$ & $\begin{array}{c}0.065 \\
(0.089)\end{array}$ & $\begin{array}{c}0.056 \\
(0.076)\end{array}$ & $\begin{array}{c}1.682^{* * *} \\
(0.159)\end{array}$ & $\begin{array}{l}0.112^{* *} \\
(0.046)\end{array}$ \\
\hline
\end{tabular}




\begin{tabular}{|c|c|c|c|c|c|c|}
\hline \multirow[b]{2}{*}{ Explanatory variables } & \multicolumn{6}{|c|}{ Dependent variables } \\
\hline & $\begin{array}{l}\text { Log of the } \\
\text { number of } \\
\text { workers }\end{array}$ & $\begin{array}{l}\text { Proportion } \\
\text { of female } \\
\text { workers }\end{array}$ & $\begin{array}{l}\text { Proportion } \\
\text { of workers } \\
\text { with social } \\
\text { insurance }\end{array}$ & $\begin{array}{c}\text { Log of } \\
\text { monthly } \\
\text { wages per } \\
\text { worker }\end{array}$ & $\begin{array}{l}\text { Log of total } \\
\text { asset }\end{array}$ & $\begin{array}{c}\text { Proportion } \\
\text { of fixed } \\
\text { asset to } \\
\text { total asset }\end{array}$ \\
\hline $\begin{array}{l}\text { Log of minimum wages * } \\
\text { Limited company }\end{array}$ & $\begin{array}{l}0.723^{\star \star *} \\
(0.103)\end{array}$ & $\begin{array}{c}0.008 \\
(0.008)\end{array}$ & $\begin{array}{l}0.109^{*} \\
(0.056)\end{array}$ & $\begin{array}{l}0.141^{* *} \\
(0.073)\end{array}$ & $\begin{array}{l}1.709^{\star \star *} \\
(0.219)\end{array}$ & $\begin{array}{c}0.176^{\star * \star} \\
(0.056)\end{array}$ \\
\hline $\begin{array}{l}\text { Log of minimum wages * } \\
\text { Joint-stock company }\end{array}$ & $\begin{array}{l}1.046^{\star * *} \\
(0.149)\end{array}$ & $\begin{array}{l}0.013^{* * *} \\
(0.003)\end{array}$ & $\begin{array}{l}0.131^{* * *} \\
(0.012)\end{array}$ & $\begin{array}{l}0.326^{* * *} \\
(0.083)\end{array}$ & $\begin{array}{l}2.119^{\star * *} \\
(0.048)\end{array}$ & $\begin{array}{l}0.156^{\star *} \\
(0.061)\end{array}$ \\
\hline $\begin{array}{l}\text { Log of minimum wages * } \\
\text { firms with FDI }\end{array}$ & $\begin{array}{l}1.173^{\star \star \star} \\
(0.082)\end{array}$ & $\begin{array}{c}-0.091^{\star * *} \\
(0.029) \\
\end{array}$ & $\begin{array}{l}0.343^{* * *} \\
(0.075)\end{array}$ & $\begin{array}{l}0.661^{* * *} \\
(0.213)\end{array}$ & $\begin{array}{l}-0.063 \\
(0.545) \\
\end{array}$ & $\begin{array}{l}0.039^{*} \\
(0.021) \\
\end{array}$ \\
\hline \multicolumn{7}{|c|}{ Model with interaction between minimum wages and business industry of firms } \\
\hline Log of minimum wages & $\begin{array}{l}-0.128 \\
(0.084)\end{array}$ & $\begin{array}{c}0.035^{\star * *} \\
(0.010)\end{array}$ & $\begin{array}{l}0.221^{* *} \\
(0.087)\end{array}$ & $\begin{array}{l}-0.014 \\
(0.148)\end{array}$ & $\begin{array}{c}0.652^{\star \star *} \\
(0.126)\end{array}$ & $\begin{array}{l}0.113^{\star * *} \\
(0.007)\end{array}$ \\
\hline $\begin{array}{l}\text { Log of minimum wages * } \\
\text { agriculture }\end{array}$ & $\begin{array}{l}-0.558^{* * *} \\
(0.135)\end{array}$ & $\begin{array}{c}0.013 \\
(0.009)\end{array}$ & $\begin{array}{l}-0.172^{* *} \\
(0.030)\end{array}$ & $\begin{array}{l}-0.263^{\star * *} \\
(0.071)\end{array}$ & $\begin{array}{l}-3.098^{* * *} \\
(0.122)\end{array}$ & $\begin{array}{l}0.007 \\
(0.065)\end{array}$ \\
\hline $\begin{array}{l}\text { Log of minimum wages * } \\
\text { Food processing }\end{array}$ & $\begin{array}{c}-0.357^{\star * *} \\
(0.025)\end{array}$ & $\begin{array}{c}-0.041^{* * *} \\
(0.010)\end{array}$ & $\begin{array}{l}-0.067^{\star *} \\
(0.029)\end{array}$ & $\begin{array}{l}0.557^{\star \star *} \\
(0.059)\end{array}$ & $\begin{array}{l}0.406^{* * *} \\
(0.003)\end{array}$ & $\begin{array}{c}-0.075^{\star \star *} \\
(0.012)\end{array}$ \\
\hline $\begin{array}{l}\text { Log of minimum wages * } \\
\text { Garment and textile }\end{array}$ & $\begin{array}{l}-0.455^{\star *} \\
(0.176)\end{array}$ & $\begin{array}{c}-0.203^{* \star *} \\
(0.023)\end{array}$ & $\begin{array}{l}0.039^{*} \\
(0.021)\end{array}$ & $\begin{array}{l}0.211^{*} \\
(0.135)\end{array}$ & $\begin{array}{c}0.004 \\
(0.168)\end{array}$ & $\begin{array}{l}-0.079^{* *} \\
(0.034)\end{array}$ \\
\hline $\begin{array}{l}\text { Log of minimum wages * } \\
\text { Wood and paper }\end{array}$ & $\begin{array}{l}-0.451^{* * *} \\
(0.077)\end{array}$ & $\begin{array}{l}0.054^{* * *} \\
(0.015)\end{array}$ & $\begin{array}{l}-0.014^{\star *} \\
(0.007)\end{array}$ & $\begin{array}{l}0.306^{\star * *} \\
(0.004)\end{array}$ & $\begin{array}{l}-0.117 \\
(0.118)\end{array}$ & $\begin{array}{c}0.028 \\
(0.018)\end{array}$ \\
\hline $\begin{array}{l}\text { Log of minimum wages * } \\
\text { Production and mining }\end{array}$ & $\begin{array}{c}-0.290^{\star * *} \\
(0.035)\end{array}$ & $\begin{array}{l}0.085^{\star * *} \\
(0.009)\end{array}$ & $\begin{array}{c}0.024 \\
(0.060)\end{array}$ & $\begin{array}{l}0.290^{* * *} \\
(0.066)\end{array}$ & $\begin{array}{c}0.083 \\
(0.118)\end{array}$ & $\begin{array}{l}-0.044^{\star *} \\
(0.022)\end{array}$ \\
\hline $\begin{array}{l}\text { Log of minimum wages * } \\
\text { Construction }\end{array}$ & $\begin{array}{l}0.265^{\star \star \star} \\
(0.015)\end{array}$ & $\begin{array}{l}0.079^{* * *} \\
(0.025)\end{array}$ & $\begin{array}{c}0.065 \\
(0.066)\end{array}$ & $\begin{array}{c}0.445^{\star \star \star \star} \\
(0.080)\end{array}$ & $\begin{array}{l}-0.089^{\star \star *} \\
(0.028)\end{array}$ & $\begin{array}{l}0.130^{\star \star *} \\
(0.017)\end{array}$ \\
\hline $\begin{array}{l}\text { Log of minimum wages * } \\
\text { Trade }\end{array}$ & $\begin{array}{l}0.066^{\star * *} \\
(0.005)\end{array}$ & $\begin{array}{l}0.023^{\star * *} \\
(0.003)\end{array}$ & $\begin{array}{l}-0.009 \\
(0.074)\end{array}$ & $\begin{array}{c}0.147 \\
(0.120)\end{array}$ & $\begin{array}{c}0.030 \\
(0.273)\end{array}$ & $\begin{array}{l}0.119^{* * *} \\
(0.006)\end{array}$ \\
\hline $\begin{array}{l}\text { Log of minimum wages * } \\
\text { Transport and services }\end{array}$ & Omitted & & & & & \\
\hline \multicolumn{7}{|c|}{ Model with interaction between minimum wages and firms' labor size } \\
\hline Log of minimum wages & $\begin{array}{c}2.242^{\star * \star} \\
(0.580)\end{array}$ & $\begin{array}{c}0.008 \\
(0.012)\end{array}$ & $\begin{array}{l}0.166^{\star \star} \\
(0.069)\end{array}$ & $\begin{array}{l}-0.139 \\
(0.080)\end{array}$ & $\begin{array}{l}2.068^{* * *} \\
(0.144)\end{array}$ & $\begin{array}{l}0.247^{\star \star *} \\
(0.012)\end{array}$ \\
\hline $\begin{array}{l}\text { Log of minimum wages * } \log \\
\text { of the number of laborers in } \\
2008\end{array}$ & $\begin{array}{c}-0.968^{* * *} \\
(0.197)\end{array}$ & $\begin{array}{l}0.020^{\star * *} \\
(0.003)\end{array}$ & $\begin{array}{c}0.028 \\
(0.046)\end{array}$ & $\begin{array}{l}0.124^{\star *} \\
(0.049)\end{array}$ & $\begin{array}{c}-0.532^{* * *} \\
(0.059)\end{array}$ & $\begin{array}{c}-0.029^{* * *} \\
(0.003)\end{array}$ \\
\hline $\begin{array}{l}\text { Note: All monetary variables } \\
{ }^{* * *} p<0.01,{ }^{* *} p<0.05,{ }^{*} p<0.1 \\
\text { Source: Estimation from EC }\end{array}$ & measured & January & & & & \\
\hline
\end{tabular}

\section{Conclusions}

Minimum wage increases often lead to debate on possibly harmful effects on employment, prices and enterprises in Vietnam. Nguyen (2009a, 2009b) do not found an significant effect of the minimum wage increase in 2005 on employment of low-wage workers and profit of firms. A possible explanation is that the increase in the real minimum wage is 
very small in 2005, at around 2 percent. Since 2008, the real minimum wages have been increasing largely, at around 15 percent annually. The effect of minimum wages in the recent period can be different from the effect of minimum wages in the previous period. Thus, this study examines the effect of minimum wages on firm outcomes during the period 2008-2010 using data from Vietnam Enterprise Censuses 2008, 2009 and 2010.

Unlike Nguyen (2009a, 2009b), we find significant effects of minimum wages on labor size and assets of firms. More specifically, a one-percent increase in real minimum wages leads to around a 0.1 percent reduction in the number of workers of firms. Male workers and workers without social insurance (low-skill and low-wage workers are less likely to have social insurance) are more likely to be affected by minimum wage increases. The average wage per worker is increased due to minimum wages, albeit at a very small magnitude. Since minimum wages reduce the number of workers and increase the wage per worker, there is no effect of the minimum wages on total labor cost of firms.

Under the pressure of minimum wages, firms tend to increase assets, especially fixed assets. To some extents, assets might be substituted for labor so that the minimum wage effects on labor cost can be reduced.

The effect of minimum wages differs for firms in different regions and firms of different types. Overall, firms in large cities and delta regions, firms with large size of labor tend to be more affected by minimum wages. By ownership types, private firms and limited companies are more likely to be affected by minimum wages than other firms.

When there is a large increase in minimum wages, minimum wages can have a harmful effect on firms in Vietnam. Although, this effect remains rather low, it can be higher if minimum wages increases by a large amount. Thus, when adjusting the minimum wage, the government of Vietnam should considering its possible unfavorable effects on firm performance. 


\section{References}

Aaronson, D. (2001), "Price Pass-through and the Minimum Wage", The Review of Economics and Statistics 83(1): 158-169.

Angrist JD., Pischke JS. (2008), Mostly Harmless Econometrics: An Empiricist's Companion. Princeton University Press.

Bauducco, S. and Janiak, A. (2012), "Minimum wages strike back: the effects on capital and labor demands in a large-firm framework", Centro de Economía Aplicada, Universidad de Chile, Chile.

Bazen, Stephen (2000) "The Impact of the Regulation of Low Wages on Inequality and Labor Market Adjustment: A Comparative Analysis." Oxford Review of Economic Policy Vol. 16, No. 1: 57-69.

Brown, C. (1999), "Minimum Wages, Employment and the Distribution of Income," In Handbook of Labor Economics, Vol. 3. Edited by O. Ashenfelter and D. Card. Elsevier Science, 1999: 2101-2163.

Brown, Charles, Curtis Gilroy, and Andrew Kohen (1982), "The Effect of the Minimum Wage on Employment and Unemployment." Journal of Economic Literature 20: 487-528

Can C. (2009), “Tăng lương sẽ không tác động nhiều đến tăng giá”, Báo Dân Trí (Newspaper Dan Tri), ngày 8/4/2009, Available at: http://dantri.com.vn/c20/s20317959/tang-luong-se-khong-tac-dong-nhieu-den-tang-gia.htm

Card, David, and Alan B. Krueger (1995), Myth and Measurement: The New Economics of the Minimum Wage. Princeton: Princeton University Press, 1995.

Card, David, and Alan B. Krueger (2000), "Minimum Wages and Employment: A Case Study of the Fast-Food Industry in New Jersey and Pennsylvania: Reply." American Economic Review. Vol. 90, No. 5: 1397-1420.

Card, David, and Alan B. Krueger. (1994), "Minimum Wages and Employment: A Case Study of the Fast- Food Industry in New Jersey and Pennsylvania." American Economic Review. Vol. 84, No. 5: 772-93.

Cunningham, W. (2007), Minimum Wages and Social Policy: Lessons from Developing Countries. World Bank, Washington.

Dickens, Richard, Stephen Machin, and Alan Manning (1999), "The Effects of Minimum Wages on Employment: Theory and Evidence from Britain.” Journal of Labor Economics 17(1): 1-22. 
Dickens, Richard, Stephen Machin, and Alan Manning, D. Metcalf, Jonathan Wadsworth, and S. Woodland (1995), “The Effect of Minimum Wages on UK Agriculture.” Journal of Agricultural Economics 46(1): 1-19.

Dolado, J. J. \& Florentino Felgueroso \& Juan F. Jimeno (2000), "The Role of the Minimum Wage in the Welfare State: An Appraisal," Swiss Journal of Economics and Statistics (SJES), Swiss Society of Economics and Statistics (SSES), vol. 136(III), 223245.

Dowrick, S., and J. Quiggin (2003). "A Survey of the Literature on Minimum Wage", Unpublished Manuscript, Australian National University.

Draca, M., Machin S., and Reenen J (2011), "Minimum Wages and Firm Profitability", American Economic Journal: Applied Economics, Vol. 3: 129-151.

Driscoll, John C. and Kraay, Aart C., (1998), "Consistent Covariance Matrix Estimation with Spatially Dependent Panel Data", Review of Economics and Statistics 80, 549-560.

Dube A., Lester W., and Reich M. (2010), "Minimum Wage Effects across State Borders: Estimates using Contiguous Counties", The Review of Economics and Statistics, 92(4): 945-964.

Duy T. (2009), "Bộ trưởng LĐTB\&XH: Nghe thì cứ tưởng là tăng lương...", VTC News, ngày 8/4/2009.

Eyraud, F. and Saget, C. (2005), The Fundamentals of Minimum Wage Fixing, International Labour Office, Geneva.

Freeman, R. B. (1994), “Minimum Wages - Again!”, International Journal of Manpower, 15(2): 8-25.

Frye, J., and R. J. Gordon (1981), "Government Intervention in the Inflation Process: The Econometrics of "Self-Inflicted Wounds", American Economic Review 71: 288-294.

Government of Vietnam (2009), "Decree on Prescribing Region-Based Minimum Wage Levels for Laborers Working For Vietnamese Companies, Enterprises, Cooperatives, Cooperative Groups, Farms, Households And Individuals And Other Vietnamese Organizations Employing Laborers” ,Decree No. 97/2009/NĐ-CP, dated on 30/10/2009, Vietnam.

Gunderson, M. (2005), "Minimum Wages In Canada: Theory, Evidence And Policy", the Federal Labor Standards Review Commission, Minimum Wage No. 512. 
Heckman J, R Lalonde, Smith J. (1999), The economics and econometrics of active labor market programs. Handbook of Labor Economics 1999; Volume 3, Ashenfelter, A. and D. Card, eds., Elsevier Science.

Hoechle, Daniel (2007), "Robust Standard Errors for Panel Regressions with CrossSectional Dependence", The Stata Journal, 7(3), 281-312.

Katz, L. F., and A. B. Krueger (1992), "The Effect of the Minimum Wage on the FastFood Industry," Industrial and Labor Relations Review 46: 6-21.

Kristensen, N. and Cunningham, W. (2006), "Do minimum wages in Latin America and the Caribbean Matter? Evidence from 19 countries “, Policy Research Working Paper (3870), World Bank Policy Research, Washington.

Lemos, Sara (2008), “A Survey of the Effects of the Minimum Wage on Prices”, Journal of Economic Survey, 22(1): 187-212.

Macdonald, J., and Aaronson D. (2000), "How Do Retail Prices React to Minimum Wage Increases?," Working Paper 2000-20, Federal Reserve Bank of Chicago.

Minh H. (2010), "Mừng ít, lo nhiều chuyện tăng lương”, Vnmedia Newspaper, on 9/4/2010, Available at http://vnmedia.vn/VN/tang_luong_toi_thieu_mung_it_lo_nhieu_23_190018.html

MOLISA (2008), “Đề án xác định lộ trình thực hiện mức lương tối thiểu thống nhất trong các loại hình doanh nghiệp giai đoạn 2008-2012" (Plan on consistent minimum wages in enterprises of all types during the period 2008-2012), Ministry of Labor, Invalid and Social Affairs of Vietnam.

Montenegro, Claudio E., and Carmen Pagés. (2004), "Who Benefits from Labor Market Regulations? Chile, 1960-1998. In James Heckman and Carmen Pagés, eds., Law and Employment: Lessons from Latin America and the Caribbean, pp. 401-34. Chicago: University of Chicago Press.

Neumark, David, and William Wascher (2007), "Minimum Wages and Employment", IZA DP Working Papers No. 2570, Institute for the Study of Labor, Bonn, German.

Nguyen, Viet Cuong (2009a), "Do Minimum Wage Increases Matter to Firm Profitability? The Case of Vietnam”, Unpublished report.

Nguyen, Viet Cuong (2009b), "The Impact of a Minimum Wage Increase on Employment, Wages and Expenditures of Workers: Evidence from Vietnam", Unpublished report. 
Nguyen, Viet Cuong (2011), "Do Minimum Wage Increases Cause Inflation? Evidence from Vietnam", ASEAN Economic Bulletin, Vol. 28(3), pp. 337-59.

Pacheco, G. and Naiker V. (2006), "Impact of the Minimum Wage on Expected Profits", International Review of Applied Economics, 20(4), 469-490

Rama, Martin. (2001), "The Consequences of Doubling the Minimum Wage: The Case of Indonesia." Industrial and Labor Relations Review, Vol. 54, No. 4: 864-81.

Thai U. (2009), “Tăng lương tối thiểu, lương hưu”, Báo Thanh Niên, ngày 06/04/2009

Tran, H., Tran T., Le D., Nguyen H. (2009), “Tiền lương tối thiểu trong kinh tế thị trường: Phương pháp xác định và phương án thời kỳ 2006-2012”, Report for Ministry of Labor, Invalid and Social Affars, Vietnam.

Wooldridge J. M. (2010), Econometric Analysis of Cross Section and Panel Data, The MIT Press, Cambridge, Massachusetts London, England.

World Bank (2006). Minimum Wages in Latin America and the Caribbean: The Impact on Employment, Inequality and Poverty, Human Development Management Unit, LAC Region., Washington, D.C. 


\section{Appendix}

Table A.1: Regressions with interaction between minimum wages and urban

\begin{tabular}{|c|c|c|c|c|c|c|}
\hline \multirow[b]{2}{*}{ Explanatory variables } & \multicolumn{6}{|c|}{ Dependent variables } \\
\hline & $\begin{array}{l}\text { Log of the } \\
\text { number of } \\
\text { workers }\end{array}$ & $\begin{array}{l}\text { Proportion } \\
\text { of female } \\
\text { workers }\end{array}$ & $\begin{array}{l}\text { Proportion } \\
\text { of workers } \\
\text { with social } \\
\text { insurance }\end{array}$ & $\begin{array}{c}\text { Log of } \\
\text { monthly } \\
\text { wages per } \\
\text { worker }\end{array}$ & $\begin{array}{l}\text { Log of total } \\
\text { asset }\end{array}$ & $\begin{array}{l}\text { Proportion } \\
\text { of fixed } \\
\text { asset to } \\
\text { total asset }\end{array}$ \\
\hline \multirow{2}{*}{ Log of minimum wages } & $-0.153^{*}$ & $0.046^{\star \star *}$ & $0.268^{* * *}$ & $0.314^{* * *}$ & $0.952^{\star \star *}$ & $0.095^{\star * *}$ \\
\hline & $(0.080)$ & $(0.004)$ & $(0.036)$ & $(0.042)$ & $(0.069)$ & $(0.013)$ \\
\hline \multirow{2}{*}{$\begin{array}{l}\text { Log of minimum wages * } \\
\text { Urban }\end{array}$} & 0.046 & $0.012^{* * *}$ & $-0.045^{\star * *}$ & $-0.217^{\star * *}$ & $-0.183^{\star *}$ & $0.074^{* * *}$ \\
\hline & $(0.031)$ & $(0.002)$ & $(0.008)$ & $(0.021)$ & $(0.073)$ & $(0.004)$ \\
\hline \multirow{2}{*}{ Year 2009} & $-0.012^{\star *}$ & $0.009^{\star * *}$ & $0.005^{\star * \star}$ & $0.212^{\star \star \star}$ & $0.057^{\star \star \star}$ & -0.002 \\
\hline & $(0.006)$ & $(0.003)$ & $(0.001)$ & $(0.018)$ & $(0.006)$ & $(0.004)$ \\
\hline \multirow{2}{*}{ Year 2010} & $0.030^{\star * *}$ & $0.014^{\star * *}$ & $0.051^{* * *}$ & $0.327^{\star * *}$ & $0.233^{\star * \star}$ & -0.013 \\
\hline & $(0.009)$ & $(0.004)$ & $(0.007)$ & $(0.022)$ & $(0.018)$ & $(0.010)$ \\
\hline \multirow{2}{*}{$\begin{array}{l}\text { Log of regional } \mathrm{CPI} \text { in } \\
\text { previous year }\end{array}$} & $0.002^{* * *}$ & $0.000^{* *}$ & 0.000 & $-0.001^{* * *}$ & $0.003^{\star * *}$ & 0.001 \\
\hline & $(0.000)$ & $(0.000)$ & $(0.000)$ & $(0.000)$ & $(0.001)$ & $(0.000)$ \\
\hline \multirow{2}{*}{$\begin{array}{l}\text { Log of lagged labor force of } \\
\text { provinces }\end{array}$} & $-0.068^{* * *}$ & -0.023 & $-0.072^{* * *}$ & $-0.430^{\star *}$ & 0.031 & -0.014 \\
\hline & $(0.011)$ & $(0.015)$ & $(0.006)$ & $(0.058)$ & $(0.134)$ & $(0.009)$ \\
\hline \multirow{6}{*}{$\begin{array}{l}\text { Log of lagged gross output } \\
\text { of agriculture per capita of } \\
\text { provinces } \\
\text { Log of lagged gross output } \\
\text { of industry per capita of } \\
\text { provinces } \\
\text { Log of lagged gross output } \\
\text { of service per capita of } \\
\text { provinces }\end{array}$} & $0.335^{\star * *}$ & $-0.033^{\star *}$ & $0.225^{\star *}$ & $0.182^{* *}$ & $0.589^{*}$ & $-0.029^{* *}$ \\
\hline & $(0.040)$ & $(0.013)$ & $(0.087)$ & $(0.066)$ & $(0.152)$ & $(0.014)$ \\
\hline & 0.003 & $-0.007^{\star *}$ & -0.007 & $0.132^{*}$ & $-0.083^{\star \star *}$ & $-0.030^{* * *}$ \\
\hline & $(0.015)$ & $(0.003)$ & $(0.013)$ & $(0.040)$ & $(0.017)$ & $(0.003)$ \\
\hline & 0.015 & $0.005^{\star}$ & $0.014^{* *}$ & $0.013^{* *}$ & -0.031 & $-0.022^{* \star *}$ \\
\hline & $(0.035)$ & $(0.003)$ & $(0.005)$ & $(0.002)$ & $(0.056)$ & $(0.005)$ \\
\hline \multirow{2}{*}{$\begin{array}{l}\text { Log of lagged regional } \\
\text { average wages }\end{array}$} & $0.061^{*}$ & -0.016 & $-0.236^{* \star *}$ & $-0.423^{*}$ & $0.254^{\star * \star}$ & $-0.074^{\star \star}$ \\
\hline & $(0.039)$ & $(0.010)$ & $(0.018)$ & $(0.108)$ & $(0.024)$ & $(0.028)$ \\
\hline \multirow{2}{*}{ Constant } & $2.829^{* * *}$ & 0.286 & $1.595^{\star * *}$ & $15.911^{\star \star *}$ & $6.590^{\star * *}$ & 0.168 \\
\hline & $(0.034)$ & $(0.211)$ & $(0.049)$ & $(0.788)$ & $(0.374)$ & $(0.251)$ \\
\hline Observations & 547,733 & 547,733 & 547,733 & 547,733 & 547,733 & 547,733 \\
\hline R-squared & 0.002 & 0.004 & 0.027 & 0.079 & 0.076 & 0.004 \\
\hline The number of firms & 205,834 & 205,834 & 205,834 & 205,834 & 205,834 & 205,834 \\
\hline \multicolumn{7}{|c|}{ 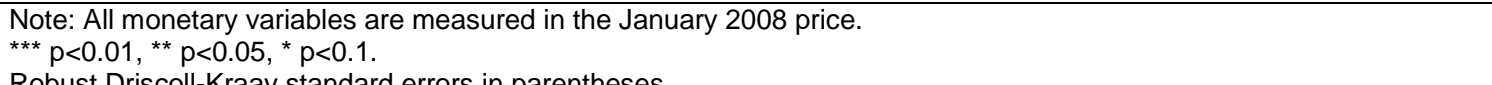 } \\
\hline
\end{tabular}


Table A.2: Regressions with interaction between minimum wages and minimum wage regions

\begin{tabular}{|c|c|c|c|c|c|c|}
\hline \multirow[b]{2}{*}{ Explanatory variables } & \multicolumn{6}{|c|}{ Dependent variables } \\
\hline & $\begin{array}{l}\text { Log of the } \\
\text { number of } \\
\text { workers }\end{array}$ & $\begin{array}{l}\text { Proportion } \\
\text { of female } \\
\text { workers }\end{array}$ & $\begin{array}{l}\text { Proportion } \\
\text { of workers } \\
\text { with social } \\
\text { insurance }\end{array}$ & $\begin{array}{l}\text { Log of } \\
\text { monthly } \\
\text { wages per } \\
\text { worker }\end{array}$ & $\begin{array}{l}\text { Log of total } \\
\text { asset }\end{array}$ & $\begin{array}{l}\text { Proportion } \\
\text { of fixed } \\
\text { asset to } \\
\text { total asset }\end{array}$ \\
\hline \multirow{2}{*}{ Log of minimum wages } & -0.148 & $0.078^{* *}$ & $0.167^{\star *}$ & $0.220^{\star *}$ & $0.610^{\star *}$ & $0.168^{* *}$ \\
\hline & $(0.116)$ & $(0.014)$ & $(0.036)$ & $(0.032)$ & $(0.108)$ & $(0.021)$ \\
\hline $\begin{array}{l}\text { Log of minimum wages * } \\
\text { minimum wage region } 1\end{array}$ & Omitted & & & & & \\
\hline \multirow{2}{*}{$\begin{array}{l}\text { Log of minimum wages * } \\
\text { minimum wage region } 2\end{array}$} & $0.172^{* \star}$ & $-0.063^{* *}$ & $0.137^{\star *}$ & $0.390^{\star \star}$ & $0.256^{*}$ & $-0.110^{\star * *}$ \\
\hline & $(0.038)$ & $(0.010)$ & $(0.019)$ & $(0.050)$ & $(0.065)$ & $(0.010)$ \\
\hline \multirow{2}{*}{$\begin{array}{l}\text { Log of minimum wages * } \\
\text { minimum wage region } 3\end{array}$} & $0.277^{*}$ & $-0.070^{\star \star}$ & $0.033^{\star *}$ & $0.470^{\star \star}$ & -0.250 & $-0.146^{\star \star}$ \\
\hline & $(0.087)$ & $(0.012)$ & $(0.005)$ & $(0.092)$ & $(0.104)$ & $(0.015)$ \\
\hline \multirow{2}{*}{$\begin{array}{l}\text { Log of minimum wages * } \\
\text { minimum wage region } 4\end{array}$} & 0.149 & -0.030 & -0.041 & $1.090^{\star \star}$ & -0.422 & $-0.198^{\star \star}$ \\
\hline & $(0.334)$ & $(0.073)$ & $(0.024)$ & $(0.250)$ & $(0.222)$ & $(0.021)$ \\
\hline \multirow{2}{*}{ Year 2009} & -0.010 & $0.008^{* *}$ & 0.006 & $0.198^{\star * *}$ & $0.060^{* * *}$ & -0.001 \\
\hline & $(0.010)$ & $(0.001)$ & $(0.003)$ & $(0.009)$ & $(0.003)$ & $(0.002)$ \\
\hline \multirow{2}{*}{ Year 2010} & 0.034 & $0.012^{\star * *}$ & $0.056^{\star *}$ & $0.299^{* * *}$ & $0.247^{\star \star \star}$ & -0.012 \\
\hline & $(0.012)$ & $(0.001)$ & $(0.010)$ & $(0.007)$ & $(0.025)$ & $(0.007)$ \\
\hline \multirow{2}{*}{$\begin{array}{l}\text { Log of regional } \mathrm{CPI} \text { in } \\
\text { previous year }\end{array}$} & 0.003 & 0.000 & 0.000 & 0.000 & 0.002 & 0.000 \\
\hline & $(0.001)$ & $(0.000)$ & $(0.000)$ & $(0.001)$ & $(0.001)$ & $(0.000)$ \\
\hline \multirow{2}{*}{$\begin{array}{l}\text { Log of lagged labor force of } \\
\text { provinces }\end{array}$} & -0.037 & $-0.030^{*}$ & $-0.080^{* *}$ & $-0.327^{* *}$ & -0.047 & $-0.039^{* *}$ \\
\hline & $(0.045)$ & $(0.009)$ & $(0.009)$ & $(0.073)$ & $(0.105)$ & $(0.007)$ \\
\hline \multirow{6}{*}{$\begin{array}{l}\text { Log of lagged gross output } \\
\text { of agriculture per capita of } \\
\text { provinces } \\
\text { Log of lagged gross output } \\
\text { of industry per capita of } \\
\text { provinces } \\
\text { Log of lagged gross output } \\
\text { of service per capita of } \\
\text { provinces }\end{array}$} & $0.280^{* *}$ & -0.022 & 0.230 & 0.114 & $0.678^{* *}$ & -0.003 \\
\hline & $(0.031)$ & $(0.015)$ & $(0.087)$ & $(0.056)$ & $(0.154)$ & $(0.021)$ \\
\hline & $-0.020^{\star *}$ & -0.002 & -0.006 & $0.091^{*}$ & $-0.048^{* *}$ & $-0.018^{\star \star}$ \\
\hline & $(0.004)$ & $(0.001)$ & $(0.010)$ & $(0.024)$ & $(0.010)$ & $(0.003)$ \\
\hline & 0.005 & 0.009 & 0.007 & -0.006 & -0.042 & $-0.017^{\star *}$ \\
\hline & $(0.033)$ & $(0.004)$ & $(0.004)$ & $(0.002)$ & $(0.046)$ & $(0.004)$ \\
\hline \multirow{2}{*}{$\begin{array}{l}\text { Log of lagged regional } \\
\text { average wages }\end{array}$} & 0.027 & $-0.010^{*}$ & $-0.231^{* * *}$ & $-0.504^{* * *}$ & $0.321^{* * *}$ & $-0.054^{\star * *}$ \\
\hline & $(0.015)$ & $(0.003)$ & $(0.007)$ & $(0.051)$ & $(0.001)$ & $(0.004)$ \\
\hline \multirow{2}{*}{ Constant } & 2.341 & 0.329 & $1.893^{* *}$ & $12.886^{\star * *}$ & $8.483^{\star * *}$ & $0.635^{*}$ \\
\hline & $(1.534)$ & $(0.152)$ & $(0.194)$ & $(0.563)$ & $(0.504)$ & $(0.150)$ \\
\hline Observations & 547,733 & 547,733 & 547,733 & 547,733 & 547,733 & 547,733 \\
\hline R-squared & 0.002 & 0.005 & 0.028 & 0.080 & 0.076 & 0.0043 \\
\hline The number of firms & 205,834 & 205,834 & 205,834 & 205,834 & 205,834 & 205,834 \\
\hline \multicolumn{7}{|c|}{$\begin{array}{l}\text { Note: All monetary variables are measured in the January } 2 \\
{ }^{* \star *} p<0.01,{ }^{\star *} p<0.05,{ }^{*} p<0.1 . \\
\text { Robust Driscoll-Kraay standard errors in parentheses. } \\
\text { Source: Estimation from EC } 2008, E C 2009 \text { and EC } 2010 .\end{array}$} \\
\hline
\end{tabular}


Table A.3: Regressions with interaction between minimum wages and geographic regions

\begin{tabular}{|c|c|c|c|c|c|c|}
\hline \multirow[b]{2}{*}{ Explanatory variables } & \multicolumn{6}{|c|}{ Dependent variables } \\
\hline & $\begin{array}{l}\text { Log of the } \\
\text { number of } \\
\text { workers }\end{array}$ & $\begin{array}{l}\text { Proportion } \\
\text { of female } \\
\text { workers }\end{array}$ & $\begin{array}{l}\text { Proportion } \\
\text { of workers } \\
\text { with social } \\
\text { insurance }\end{array}$ & $\begin{array}{l}\text { Log of } \\
\text { monthly } \\
\text { wages per } \\
\text { worker }\end{array}$ & $\begin{array}{l}\text { Log of total } \\
\text { asset }\end{array}$ & $\begin{array}{l}\text { Proportion } \\
\text { of fixed } \\
\text { asset to } \\
\text { total asset }\end{array}$ \\
\hline \multirow{2}{*}{ Log of minimum wages } & $0.212^{\star *}$ & $0.101^{* *}$ & $0.249^{* *}$ & $0.705^{\star *}$ & $0.472^{\star *}$ & -0.000 \\
\hline & $(0.079)$ & $(0.022)$ & $(0.090)$ & $(0.145)$ & $(0.181)$ & $(0.021)$ \\
\hline \multicolumn{7}{|l|}{$\begin{array}{l}\text { Log of minimum wages * } \\
\text { Northern Mountain }\end{array}$} \\
\hline \multirow{2}{*}{$\begin{array}{l}\text { Log of minimum wages * } \\
\text { Red River Delta }\end{array}$} & $-0.314^{\star * \star}$ & -0.038 & 0.009 & $-0.290^{\star *}$ & 0.319 & $0.071^{\star * *}$ \\
\hline & $(0.027)$ & $(0.038)$ & $(0.023)$ & $(0.147)$ & $(0.225)$ & $(0.010)$ \\
\hline \multirow{2}{*}{$\begin{array}{l}\text { Log of minimum wages * } \\
\text { Central Coast }\end{array}$} & -0.039 & $-0.078^{\star *}$ & $0.076^{* * *}$ & $-0.376^{\star * *}$ & 0.063 & $0.179^{* * *}$ \\
\hline & $(0.031)$ & $(0.033)$ & $(0.008)$ & $(0.056)$ & $(0.107)$ & $(0.029)$ \\
\hline \multirow{2}{*}{$\begin{array}{l}\text { Log of minimum wages * } \\
\text { Highlands }\end{array}$} & -0.100 & $-0.136^{\star * \star}$ & $-0.012^{\star}$ & $-0.853^{\star \star \star}$ & $0.957^{\star \star \star}$ & -0.003 \\
\hline & $(0.087)$ & $(0.017)$ & $(0.070)$ & $(0.103)$ & $(0.043)$ & $(0.090)$ \\
\hline \multirow{2}{*}{$\begin{array}{l}\text { Log of minimum wages * } \\
\text { South East }\end{array}$} & $-0.346^{* * *}$ & $-0.041^{* *}$ & -0.088 & $-1.005^{\star * *}$ & $0.268^{* * *}$ & $0.274^{\star * *}$ \\
\hline & $(0.081)$ & $(0.020)$ & $(0.141)$ & $(0.114)$ & $(0.081)$ & $(0.024)$ \\
\hline \multirow{2}{*}{$\begin{array}{l}\text { Log of minimum wages * } \\
\text { Mekong River Delta }\end{array}$} & $-0.147^{\star * *}$ & $-0.185^{\star * *}$ & 0.019 & $-0.434^{\star *}$ & 0.118 & $0.112^{\star \star}$ \\
\hline & $(0.020)$ & $(0.009)$ & $(0.020)$ & $(0.171)$ & $(0.151)$ & $(0.052)$ \\
\hline \multirow{2}{*}{ Year 2009} & -0.011 & $0.008^{* * *}$ & $0.007^{\star * *}$ & $0.229^{* * *}$ & $0.062^{* * *}$ & $-0.007^{*}$ \\
\hline & $(0.006)$ & $(0.002)$ & $(0.002)$ & $(0.011)$ & $(0.015)$ & $(0.004)$ \\
\hline \multirow{2}{*}{ Year 2010} & $0.035^{\star \star \star}$ & $0.013^{\star * *}$ & $0.059^{\star * *}$ & $0.367^{* * *}$ & $0.244^{\star * *}$ & $-0.025^{\star \star *}$ \\
\hline & $(0.007)$ & $(0.004)$ & $(0.005)$ & $(0.005)$ & $(0.029)$ & $(0.004)$ \\
\hline \multirow{2}{*}{$\begin{array}{l}\text { Log of regional } \mathrm{CPI} \text { in } \\
\text { previous year }\end{array}$} & $0.003^{* *}$ & 0.000 & $0.001^{* * *}$ & -0.000 & $0.003^{* *}$ & $0.000^{* * *}$ \\
\hline & $(0.001)$ & $(0.000)$ & $(0.000)$ & $(0.000)$ & $(0.000)$ & $(0.000)$ \\
\hline \multirow{2}{*}{$\begin{array}{l}\text { Log of lagged labor force of } \\
\text { provinces }\end{array}$} & -0.024 & $-0.043^{* *}$ & -0.024 & $-0.132^{*}$ & 0.000 & $-0.087^{* * *}$ \\
\hline & $(0.048)$ & $(0.020)$ & $(0.052)$ & $(0.076)$ & $(0.202)$ & $(0.005)$ \\
\hline \multirow{6}{*}{$\begin{array}{l}\text { Log of lagged gross output } \\
\text { of agriculture per capita of } \\
\text { provinces } \\
\text { Log of lagged gross output } \\
\text { of industry per capita of } \\
\text { provinces } \\
\text { Log of lagged gross output } \\
\text { of service per capita of } \\
\text { provinces }\end{array}$} & $0.282^{* \star *}$ & $-0.026^{*}$ & $0.189^{* *}$ & -0.059 & $0.559^{* * *}$ & $0.055^{\star \star \star}$ \\
\hline & $(0.029)$ & $(0.016)$ & $(0.084)$ & $(0.049)$ & $(0.171)$ & $(0.014)$ \\
\hline & $-0.020^{* *}$ & $-0.003^{\star *}$ & $-0.019^{\star *}$ & $0.081^{\star *}$ & $-0.072^{\star * *}$ & $-0.019^{* * *}$ \\
\hline & $(0.008)$ & $(0.001)$ & $(0.008)$ & $(0.042)$ & $(0.019)$ & $(0.003)$ \\
\hline & 0.018 & $0.006^{\star *}$ & $0.018^{\star * *}$ & $0.037^{\star * *}$ & -0.037 & $-0.026^{\star *}$ \\
\hline & $(0.027)$ & $(0.003)$ & $(0.001)$ & $(0.004)$ & $(0.050)$ & $(0.004)$ \\
\hline \multirow{2}{*}{$\begin{array}{l}\text { Log of lagged regional } \\
\text { average wages }\end{array}$} & 0.025 & -0.006 & $-0.256^{\star * *}$ & $-0.532^{\star * *}$ & $0.274^{\star * *}$ & $-0.048^{* *}$ \\
\hline & $(0.018)$ & $(0.005)$ & $(0.026)$ & $(0.056)$ & $(0.078)$ & $(0.017)$ \\
\hline \multirow{2}{*}{ Constant } & $2.248^{\star \star \star}$ & $0.431^{\star *}$ & $1.434^{\star \star \star}$ & $14.963^{\star \star \star}$ & $7.266^{\star \star \star}$ & $0.375^{\star}$ \\
\hline & $(0.558)$ & $(0.184)$ & $(0.366)$ & $(0.409)$ & $(0.273)$ & $(0.213)$ \\
\hline Observations & 547,733 & 547,733 & 547,733 & 547,733 & 547,733 & 547,733 \\
\hline R-squared & 0.002 & 0.005 & 0.028 & 0.082 & 0.076 & 0.005 \\
\hline The number of firms & 205,834 & 205,834 & 205,834 & 205,834 & 205,834 & 205,834 \\
\hline \multicolumn{7}{|c|}{$\begin{array}{l}\text { Note: All monetary variables are measured in the January } 2 \\
{ }^{* * *} p<0.01,{ }^{* *} p<0.05,{ }^{*} p<0.1 . \\
\text { Robust Driscoll-Kraay standard errors in parentheses. } \\
\text { Source: Estimation from EC } 2008, E C 2009 \text { and EC } 2010 .\end{array}$} \\
\hline
\end{tabular}


Table A.4: Regressions with interaction between minimum wages and provinces

\begin{tabular}{|c|c|c|c|c|c|c|}
\hline \multirow[b]{2}{*}{ Explanatory variables } & \multicolumn{6}{|c|}{ Dependent variables } \\
\hline & $\begin{array}{l}\text { Log of the } \\
\text { number of } \\
\text { workers }\end{array}$ & $\begin{array}{l}\text { Proportion } \\
\text { of female } \\
\text { workers }\end{array}$ & $\begin{array}{l}\text { Proportion } \\
\text { of workers } \\
\text { with social } \\
\text { insurance }\end{array}$ & $\begin{array}{l}\text { Log of } \\
\text { monthly } \\
\text { wages per } \\
\text { worker }\end{array}$ & $\begin{array}{l}\text { Log of total } \\
\text { asset }\end{array}$ & $\begin{array}{l}\text { Proportion } \\
\text { of fixed } \\
\text { asset to } \\
\text { total asset }\end{array}$ \\
\hline \multirow{2}{*}{ Log of minimum wages } & $0.219^{* * *}$ & -0.003 & $0.307^{\star *}$ & $0.372^{\star * *}$ & $0.648^{\star * *}$ & $0.094^{* * *}$ \\
\hline & $(0.071)$ & $(0.009)$ & $(0.049)$ & $(0.090)$ & $(0.147)$ & $(0.012)$ \\
\hline \multirow{2}{*}{$\begin{array}{l}\text { Log of minimum wages * } \\
\text { Hanoi }\end{array}$} & $-0.288^{* * *}$ & $0.073^{* *}$ & -0.071 & 0.091 & 0.141 & 0.009 \\
\hline & $(0.010)$ & $(0.026)$ & $(0.082)$ & $(0.082)$ & $(0.290)$ & $(0.013)$ \\
\hline \multirow{2}{*}{$\begin{array}{l}\text { Log of minimum wages * Hai } \\
\text { Phong }\end{array}$} & $-0.345^{\star * *}$ & 0.038 & $0.124^{\star \star *}$ & -0.337 & $0.409^{\star *}$ & $-0.141^{\star * *}$ \\
\hline & $(0.037)$ & $(0.037)$ & $(0.039)$ & $(0.165)$ & $(0.185)$ & $(0.027)$ \\
\hline \multirow{2}{*}{$\begin{array}{l}\text { Log of minimum wages * } \\
\text { Binh Duong }\end{array}$} & $-0.761^{* * *}$ & $-0.080^{\star *}$ & $0.143^{\star *}$ & -0.022 & -0.239 & 0.020 \\
\hline & $(0.081)$ & $(0.038)$ & $(0.049)$ & $(0.122)$ & $(0.370)$ & $(0.070)$ \\
\hline \multirow{2}{*}{$\begin{array}{l}\text { Log of minimum wages * } \\
\text { Dong Nai }\end{array}$} & -0.171 & $-0.074^{*}$ & $-0.401^{* * *}$ & -0.104 & $-0.297^{* *}$ & $0.143^{\star * *}$ \\
\hline & $(0.117)$ & $(0.042)$ & $(0.094)$ & $(0.315)$ & $(0.104)$ & $(0.009)$ \\
\hline \multirow{2}{*}{$\begin{array}{l}\text { Log of minimum wages * Ho } \\
\text { Chi Minh city }\end{array}$} & $-0.355^{\star \star *}$ & $0.066^{\star *}$ & -0.124 & $-0.473^{\star \star *}$ & $0.054^{\star *}$ & $0.185^{\star \star \star}$ \\
\hline & $(0.053)$ & $(0.010)$ & $(0.098)$ & $(0.080)$ & $(0.027)$ & $(0.008)$ \\
\hline $\begin{array}{l}\text { Log of minimum wages * } \\
\text { Other provinces }\end{array}$ & Omitted & & & & & \\
\hline \multirow{2}{*}{ Year 2009} & $-0.014^{\star *}$ & $0.008^{* * *}$ & $0.007^{* *}$ & $0.236^{\star * *}$ & $0.061^{* * *}$ & $-0.007^{* * *}$ \\
\hline & $(0.007)$ & $(0.001)$ & $(0.003)$ & $(0.010)$ & $(0.013)$ & $(0.001)$ \\
\hline \multirow{2}{*}{ Year 2010} & $0.031^{* \star *}$ & $0.013^{\star * *}$ & $0.056^{\star * *}$ & $0.380^{\star \star *}$ & $0.243^{\star * *}$ & $-0.026^{\star \star *}$ \\
\hline & $(0.004)$ & $(0.002)$ & $(0.006)$ & $(0.008)$ & $(0.032)$ & $(0.003)$ \\
\hline \multirow{2}{*}{$\begin{array}{l}\text { Log of regional } \mathrm{CPI} \text { in } \\
\text { previous year }\end{array}$} & $0.003^{\star * *}$ & 0.000 & $0.000^{* * *}$ & 0.000 & $0.003^{\star * *}$ & 0.000 \\
\hline & $(0.001)$ & $(0.000)$ & $(0.000)$ & $(0.000)$ & $(0.000)$ & $(0.000)$ \\
\hline \multirow{2}{*}{$\begin{array}{l}\text { Log of lagged labor force of } \\
\text { provinces }\end{array}$} & $0.159^{\star \star \star}$ & -0.002 & $-0.062^{\star \star \star}$ & $-0.356^{\star * *}$ & 0.135 & $-0.055^{\star \star *}$ \\
\hline & $(0.047)$ & $(0.007)$ & $(0.019)$ & $(0.063)$ & $(0.217)$ & $(0.018)$ \\
\hline \multirow{2}{*}{$\begin{array}{l}\text { Log of lagged gross output } \\
\text { of agriculture per capita of } \\
\text { provinces }\end{array}$} & $0.273^{\star * \star}$ & $-0.025^{\star * \star}$ & $0.205^{\star \star}$ & $-0.149^{* *}$ & $0.562^{\star * \star}$ & $0.055^{\star * *}$ \\
\hline & $(0.033)$ & $(0.007)$ & $(0.084)$ & $(0.075)$ & $(0.159)$ & $(0.018)$ \\
\hline \multirow{2}{*}{$\begin{array}{l}\text { Log of lagged gross output } \\
\text { of industry per capita of } \\
\text { provinces }\end{array}$} & -0.027 & 0.000 & $-0.015^{\star}$ & $0.065^{\star *}$ & $-0.072^{\star * \star}$ & $-0.015^{\star \star *}$ \\
\hline & $(0.012)$ & $(0.001)$ & $(0.008)$ & $(0.026)$ & $(0.016)$ & $(0.001)$ \\
\hline \multirow{2}{*}{$\begin{array}{l}\text { Log of lagged gross output } \\
\text { of service per capita of } \\
\text { provinces }\end{array}$} & 0.026 & $0.014^{\star * *}$ & 0.001 & 0.003 & -0.005 & $-0.020^{\star \star *}$ \\
\hline & $(0.027)$ & $(0.002)$ & $(0.002)$ & $(0.009)$ & $(0.028)$ & $(0.005)$ \\
\hline \multirow{2}{*}{$\begin{array}{l}\text { Log of lagged regional } \\
\text { average wages }\end{array}$} & $-0.026^{\star \star \star}$ & $-0.015^{\star \star \star}$ & $-0.248^{\star * *}$ & $-0.493^{\star * *}$ & $0.244^{\star \star *}$ & $-0.054^{\star * *}$ \\
\hline & $(0.003)$ & $(0.004)$ & $(0.009)$ & $(0.021)$ & $(0.066)$ & $(0.007)$ \\
\hline \multirow{2}{*}{ Constant } & $1.018^{\star}$ & $0.301^{* * *}$ & $1.532^{* * *}$ & $15.984^{\star * *}$ & $6.742^{\star *}$ & $0.259^{* * *}$ \\
\hline & $(0.538)$ & $(0.037)$ & $(0.144)$ & $(0.323)$ & $(0.706)$ & $(0.029)$ \\
\hline Observations & 547,733 & 547,733 & 547,733 & 547,733 & 547,733 & 547,733 \\
\hline R-squared & 0.002 & 0.005 & 0.029 & 0.083 & 0.076 & 0.005 \\
\hline The number of firms & 205,834 & 205,834 & 205,834 & 205,834 & 205,834 & 205,834 \\
\hline \multicolumn{7}{|c|}{$\begin{array}{l}\text { Note: All monetary variables are measured in the January } 2 \\
{ }^{* \star *} p<0.01,{ }^{* \star} p<0.05,{ }^{*} p<0.1 . \\
\text { Robust Driscoll-Kraay standard errors in parentheses. } \\
\text { Source: Estimation from EC } 2008, E C 2009 \text { and EC } 2010 .\end{array}$} \\
\hline
\end{tabular}


Table A.5: Regressions with interaction between minimum wages and firm types

\begin{tabular}{|c|c|c|c|c|c|c|}
\hline \multirow[b]{2}{*}{ Explanatory variables } & \multicolumn{6}{|c|}{ Dependent variables } \\
\hline & $\begin{array}{l}\text { Log of the } \\
\text { number of } \\
\text { workers }\end{array}$ & $\begin{array}{l}\text { Proportion } \\
\text { of female } \\
\text { workers }\end{array}$ & $\begin{array}{l}\text { Proportion } \\
\text { of workers } \\
\text { with social } \\
\text { insurance }\end{array}$ & $\begin{array}{l}\text { Log of } \\
\text { monthly } \\
\text { wages per } \\
\text { worker }\end{array}$ & $\begin{array}{l}\text { Log of total } \\
\text { asset }\end{array}$ & $\begin{array}{l}\text { Proportion } \\
\text { of fixed } \\
\text { asset to } \\
\text { total asset }\end{array}$ \\
\hline \multirow{2}{*}{ Log of minimum wages } & $-0.913^{\star * *}$ & $0.052^{* * *}$ & 0.120 & -0.024 & $-1.078^{\star * \star}$ & 0.000 \\
\hline & $(0.089)$ & $(0.004)$ & $(0.094)$ & $(0.156)$ & $(0.175)$ & $(0.063)$ \\
\hline \multirow{2}{*}{$\begin{array}{l}\text { Log of minimum wages * } \\
\text { State firms }\end{array}$} & $0.163^{* * *}$ & $-0.060^{* *}$ & -0.023 & $-0.123^{\star *}$ & $-0.100^{* *}$ & $0.163^{* * *}$ \\
\hline & $(0.055)$ & $(0.009)$ & $(0.044)$ & $(0.051)$ & $(0.043)$ & $(0.054)$ \\
\hline $\begin{array}{l}\text { Log of minimum wages * } \\
\text { Collectives }\end{array}$ & Omitted & & & & & \\
\hline \multirow{2}{*}{$\begin{array}{l}\text { Log of minimum wages * } \\
\text { Private firms }\end{array}$} & $0.456^{\star \star \star}$ & $-0.037^{* * *}$ & 0.065 & 0.056 & $1.682^{* \star *}$ & $0.112^{\star \star}$ \\
\hline & $(0.122)$ & $(0.010)$ & $(0.089)$ & $(0.076)$ & $(0.159)$ & $(0.046)$ \\
\hline \multirow{2}{*}{$\begin{array}{l}\text { Log of minimum wages * } \\
\text { Limited company }\end{array}$} & $0.723^{\star * *}$ & 0.008 & $0.109^{*}$ & $0.141^{\star *}$ & $1.709^{\star * \star}$ & $0.176^{\star * *}$ \\
\hline & $(0.103)$ & $(0.008)$ & $(0.056)$ & $(0.073)$ & $(0.219)$ & $(0.056)$ \\
\hline \multirow{2}{*}{$\begin{array}{l}\text { Log of minimum wages * } \\
\text { Joint-stock company }\end{array}$} & $1.046^{* * *}$ & $0.013^{\star * *}$ & $0.131^{* * *}$ & $0.326^{\star * *}$ & $2.119^{\star * \star}$ & $0.156^{\star *}$ \\
\hline & $(0.149)$ & $(0.003)$ & $(0.012)$ & $(0.083)$ & $(0.048)$ & $(0.061)$ \\
\hline \multirow{2}{*}{$\begin{array}{l}\text { Log of minimum wages * } \\
\text { firms with FDI }\end{array}$} & $1.173^{* * *}$ & $-0.091^{* * *}$ & $0.343^{* * *}$ & $0.661^{* * *}$ & -0.063 & $0.039^{*}$ \\
\hline & $(0.082)$ & $(0.029)$ & $(0.075)$ & $(0.213)$ & $(0.545)$ & $(0.021)$ \\
\hline \multirow{2}{*}{ Year 2009} & $0.011^{* * *}$ & $0.007^{\star * *}$ & $0.011^{* * *}$ & $0.257^{\star \star *}$ & $0.076^{\star * *}$ & -0.002 \\
\hline & $(0.001)$ & $(0.001)$ & $(0.003)$ & $(0.004)$ & $(0.007)$ & $(0.004)$ \\
\hline \multirow{2}{*}{ Year 2010} & $0.038^{\star *}$ & $0.013^{* * *}$ & $0.056^{\star * *}$ & $0.353^{* * *}$ & $0.280^{\star * *}$ & $-0.018^{\star *}$ \\
\hline & $(0.008)$ & $(0.003)$ & $(0.009)$ & $(0.006)$ & $(0.020)$ & $(0.008)$ \\
\hline \multirow{2}{*}{$\begin{array}{l}\text { Log of regional CPI in } \\
\text { previous year }\end{array}$} & 0.002 & 0.000 & 0.000 & -0.001 & 0.002 & 0.000 \\
\hline & $(0.001)$ & $(0.000)$ & $(0.000)$ & $(0.000)$ & $(0.001)$ & $(0.000)$ \\
\hline \multirow{2}{*}{$\begin{array}{l}\text { Log of lagged labor force of } \\
\text { provinces }\end{array}$} & $-0.075^{\star \star \star}$ & -0.020 & $-0.087^{* * *}$ & $-0.409^{* * *}$ & -0.038 & -0.016 \\
\hline & $(0.012)$ & $(0.014)$ & $(0.009)$ & $(0.062)$ & $(0.164)$ & $(0.018)$ \\
\hline \multirow{2}{*}{$\begin{array}{l}\text { Log of lagged gross output } \\
\text { of agriculture per capita of } \\
\text { provinces }\end{array}$} & $0.306^{\star \star \star *}$ & $-0.027^{\star \star}$ & $0.203^{\star *}$ & 0.131 & $0.465^{\star *}$ & -0.017 \\
\hline & $(0.033)$ & $(0.011)$ & $(0.093)$ & $(0.080)$ & $(0.175)$ & $(0.025)$ \\
\hline \multirow{2}{*}{$\begin{array}{l}\text { Log of lagged gross output } \\
\text { of industry per capita of } \\
\text { provinces }\end{array}$} & $0.023^{*}$ & $-0.008^{\star \star \star}$ & 0.001 & $0.151^{* \star *}$ & $-0.073^{\star \star \star}$ & $-0.025^{\star \star *}$ \\
\hline & $(0.015)$ & $(0.001)$ & $(0.012)$ & $(0.035)$ & $(0.015)$ & $(0.005)$ \\
\hline \multirow{2}{*}{$\begin{array}{l}\text { Log of lagged gross output } \\
\text { of service per capita of } \\
\text { provinces }\end{array}$} & 0.010 & 0.005 & $0.014^{\star \star \star}$ & 0.009 & -0.018 & $-0.025^{\star * *}$ \\
\hline & $(0.027)$ & $(0.003)$ & $(0.005)$ & $(0.007)$ & $(0.043)$ & $(0.006)$ \\
\hline \multirow{2}{*}{$\begin{array}{l}\text { Log of lagged regional } \\
\text { average wages }\end{array}$} & 0.042 & -0.006 & $-0.253^{* * *}$ & $-0.600^{\star \star \star}$ & $0.252^{\star * \star}$ & $-0.064^{*}$ \\
\hline & $(0.050)$ & $(0.007)$ & $(0.024)$ & $(0.087)$ & $(0.069)$ & $(0.036)$ \\
\hline \multirow{2}{*}{ Constant } & $4.029^{\star * \star}$ & $0.222^{*}$ & $1.955^{\star * *}$ & $17.634^{\star \star *}$ & $9.264^{\star * *}$ & 0.162 \\
\hline & $(0.142)$ & $(0.134)$ & $(0.105)$ & $(0.270)$ & $(0.842)$ & $(0.165)$ \\
\hline Observations & 447,245 & 447,245 & 447,245 & 447,245 & 447,245 & 447,245 \\
\hline R-squared & 0.004 & 0.005 & 0.022 & 0.084 & 0.088 & 0.004 \\
\hline The number of firms & 155,590 & 155,590 & 155,590 & 155,590 & 155,590 & 155,590 \\
\hline \multicolumn{7}{|c|}{$\begin{array}{l}\text { Note: All monetary variables are measured in the January } 20 \\
{ }^{* \star *} p<0.01,{ }^{* *} p<0.05,{ }^{*} p<0.1 . \\
\text { Robust Driscoll-Kraay standard errors in parentheses. } \\
\text { Source: Estimation from EC } 2008, E C 2009 \text { and EC } 2010 .\end{array}$} \\
\hline
\end{tabular}


Table A.6: Regressions with interaction between minimum wages and industry of firms

\begin{tabular}{|c|c|c|c|c|c|c|}
\hline \multirow[b]{2}{*}{ Explanatory variables } & \multicolumn{6}{|c|}{ Dependent variables } \\
\hline & $\begin{array}{l}\text { Log of the } \\
\text { number of } \\
\text { workers }\end{array}$ & $\begin{array}{l}\text { Proportion } \\
\text { of female } \\
\text { workers }\end{array}$ & $\begin{array}{l}\text { Proportion } \\
\text { of workers } \\
\text { with social } \\
\text { insurance }\end{array}$ & $\begin{array}{l}\text { Log of } \\
\text { monthly } \\
\text { wages per } \\
\text { worker }\end{array}$ & $\begin{array}{l}\text { Log of total } \\
\text { asset }\end{array}$ & $\begin{array}{l}\text { Proportion } \\
\text { of fixed } \\
\text { asset to } \\
\text { total asset }\end{array}$ \\
\hline \multirow{2}{*}{ Log of minimum wages } & -0.128 & $0.035^{\star * *}$ & $0.221^{* *}$ & -0.014 & $0.652^{* * *}$ & $0.113^{\star \star \star}$ \\
\hline & $(0.084)$ & $(0.010)$ & $(0.087)$ & $(0.148)$ & $(0.126)$ & $(0.007)$ \\
\hline \multirow{2}{*}{$\begin{array}{l}\text { Log of minimum wages * } \\
\text { agriculture }\end{array}$} & $-0.558^{* * *}$ & 0.013 & $-0.172^{\star *}$ & $-0.263^{* * *}$ & $-3.098^{\star \star *}$ & 0.007 \\
\hline & $(0.135)$ & $(0.009)$ & $(0.030)$ & $(0.071)$ & $(0.122)$ & $(0.065)$ \\
\hline \multirow{2}{*}{$\begin{array}{l}\text { Log of minimum wages * } \\
\text { Food processing }\end{array}$} & $-0.357^{\star * *}$ & $-0.041^{* * *}$ & $-0.067^{\star *}$ & $0.557^{\star \star *}$ & $0.406^{\star \star *}$ & $-0.075^{\star \star \star}$ \\
\hline & $(0.025)$ & $(0.010)$ & $(0.029)$ & $(0.059)$ & $(0.003)$ & $(0.012)$ \\
\hline \multirow{2}{*}{$\begin{array}{l}\text { Log of minimum wages * } \\
\text { Garment and textile }\end{array}$} & $-0.455^{\star *}$ & $-0.203^{* * *}$ & $0.039^{*}$ & $0.211^{*}$ & 0.004 & $-0.079^{* *}$ \\
\hline & $(0.176)$ & $(0.023)$ & $(0.021)$ & $(0.135)$ & $(0.168)$ & $(0.034)$ \\
\hline \multirow{2}{*}{$\begin{array}{l}\text { Log of minimum wages * } \\
\text { Wood and paper }\end{array}$} & $-0.451^{* * *}$ & $0.054^{* * *}$ & $-0.014^{* \star}$ & $0.306^{* * *}$ & -0.117 & 0.028 \\
\hline & $(0.077)$ & $(0.015)$ & $(0.007)$ & $(0.004)$ & $(0.118)$ & $(0.018)$ \\
\hline \multirow{2}{*}{$\begin{array}{l}\text { Log of minimum wages * } \\
\text { Production and mining }\end{array}$} & $-0.290^{* * *}$ & $0.085^{\star * *}$ & 0.024 & $0.290^{\star \star *}$ & 0.083 & $-0.044^{\star \star}$ \\
\hline & $(0.035)$ & $(0.009)$ & $(0.060)$ & $(0.066)$ & $(0.118)$ & $(0.022)$ \\
\hline \multirow{2}{*}{$\begin{array}{l}\text { Log of minimum wages * } \\
\text { Construction }\end{array}$} & $0.265^{\star \star \star}$ & $0.079^{\star * *}$ & 0.065 & $0.445^{\star * * *}$ & $-0.089^{* * *}$ & $0.130^{\star * \star}$ \\
\hline & $(0.015)$ & $(0.025)$ & $(0.066)$ & $(0.080)$ & $(0.028)$ & $(0.017)$ \\
\hline \multirow{2}{*}{$\begin{array}{l}\text { Log of minimum wages * } \\
\text { Trade }\end{array}$} & $0.066^{* * *}$ & $0.023^{* * *}$ & -0.009 & 0.147 & 0.030 & $0.119^{\star * *}$ \\
\hline & $(0.005)$ & $(0.003)$ & $(0.074)$ & $(0.120)$ & $(0.273)$ & $(0.006)$ \\
\hline $\begin{array}{l}\text { Log of minimum wages * } \\
\text { Transport and services }\end{array}$ & Omitted & & & & & \\
\hline \multirow{2}{*}{ Year 2009} & 0.005 & $0.006^{\star * *}$ & $0.011^{* * *}$ & $0.253^{* * *}$ & $0.076^{\star * *}$ & -0.003 \\
\hline & $(0.004)$ & $(0.002)$ & $(0.003)$ & $(0.005)$ & $(0.007)$ & $(0.004)$ \\
\hline \multirow{2}{*}{ Year 2010} & $0.030^{\star * *}$ & $0.012^{* * *}$ & $0.055^{\star * *}$ & $0.347^{\star * *}$ & $0.281^{* * *}$ & $-0.020^{* *}$ \\
\hline & $(0.008)$ & $(0.003)$ & $(0.010)$ & $(0.004)$ & $(0.021)$ & $(0.009)$ \\
\hline \multirow{2}{*}{$\begin{array}{l}\text { Log of regional CPI in } \\
\text { previous year }\end{array}$} & $0.002^{* *}$ & $0.000^{\star * *}$ & 0.000 & -0.001 & $0.002^{\star \star}$ & 0.000 \\
\hline & $(0.001)$ & $(0.000)$ & $(0.000)$ & $(0.001)$ & $(0.001)$ & $(0.000)$ \\
\hline \multirow{2}{*}{$\begin{array}{l}\text { Log of lagged labor force of } \\
\text { provinces }\end{array}$} & $-0.051^{\star \star *}$ & $-0.023^{*}$ & $-0.086^{\star \star \star}$ & $-0.412^{\star \star \star}$ & -0.073 & -0.008 \\
\hline & $(0.008)$ & $(0.014)$ & $(0.009)$ & $(0.066)$ & $(0.179)$ & $(0.018)$ \\
\hline \multirow{2}{*}{$\begin{array}{l}\text { Log of lagged gross output } \\
\text { of agriculture per capita of } \\
\text { provinces }\end{array}$} & $0.303^{* \star *}$ & $-0.032^{\star *}$ & $0.202^{\star *}$ & 0.145 & $0.516^{* *}$ & -0.024 \\
\hline & $(0.046)$ & $(0.012)$ & $(0.096)$ & $(0.091)$ & $(0.181)$ & $(0.025)$ \\
\hline \multirow{2}{*}{$\begin{array}{l}\text { Log of lagged gross output } \\
\text { of industry per capita of } \\
\text { provinces }\end{array}$} & 0.016 & $-0.010^{* * *}$ & -0.000 & $0.147^{* * *}$ & $-0.073^{\star * *}$ & $-0.026^{\star * *}$ \\
\hline & $(0.012)$ & $(0.002)$ & $(0.011)$ & $(0.033)$ & $(0.021)$ & $(0.005)$ \\
\hline \multirow{2}{*}{$\begin{array}{l}\text { Log of lagged gross output } \\
\text { of service per capita of } \\
\text { provinces }\end{array}$} & 0.009 & 0.004 & $0.014^{* *}$ & 0.006 & -0.027 & $-0.025^{\star \star *}$ \\
\hline & $(0.026)$ & $(0.004)$ & $(0.006)$ & $(0.006)$ & $(0.047)$ & $(0.006)$ \\
\hline \multirow{2}{*}{$\begin{array}{l}\text { Log of lagged regional } \\
\text { average wages }\end{array}$} & 0.031 & -0.006 & $-0.252^{* * *}$ & $-0.598^{\star * *}$ & $0.253^{\star * *}$ & $-0.066^{\star}$ \\
\hline & $(0.038)$ & $(0.011)$ & $(0.025)$ & $(0.079)$ & $(0.068)$ & $(0.039)$ \\
\hline \multirow{2}{*}{ Constant } & $3.412^{* \star *}$ & 0.141 & $1.924^{\star \star *}$ & $17.397^{\star \star \star}$ & $9.290^{* \star *}$ & -0.035 \\
\hline & $(0.150)$ & $(0.166)$ & $(0.152)$ & $(0.239)$ & $(0.819)$ & $(0.193)$ \\
\hline Observations & 447,245 & 447,245 & 447,245 & 447,245 & 447,245 & 447,245 \\
\hline R-squared & 0.003 & 0.007 & 0.022 & 0.085 & 0.088 & 0.005 \\
\hline The number of firms & 155,590 & 155,590 & 155,590 & 155,590 & 155,590 & 155,590 \\
\hline \multicolumn{7}{|c|}{$\begin{array}{l}\text { Note: All monetary variables are measured in the January } 2 \\
{ }^{* * *} p<0.01,{ }^{* \star} p<0.05,{ }^{*} p<0.1 . \\
\text { Robust Driscoll-Kraay standard errors in parentheses. } \\
\text { Source: Estimation from EC } 2008, E C 2009 \text { and EC } 2010 \text {. }\end{array}$} \\
\hline
\end{tabular}


Table A.7: Regressions with interaction between minimum wages and firms' labor size

\begin{tabular}{|c|c|c|c|c|c|c|}
\hline \multirow[b]{2}{*}{ Explanatory variables } & \multicolumn{6}{|c|}{ Dependent variables } \\
\hline & $\begin{array}{l}\text { Log of the } \\
\text { number of } \\
\text { workers }\end{array}$ & $\begin{array}{l}\text { Proportion } \\
\text { of female } \\
\text { workers }\end{array}$ & $\begin{array}{l}\text { Proportion } \\
\text { of workers } \\
\text { with social } \\
\text { insurance }\end{array}$ & $\begin{array}{l}\text { Log of } \\
\text { monthly } \\
\text { wages per } \\
\text { worker }\end{array}$ & $\begin{array}{l}\text { Log of total } \\
\text { asset }\end{array}$ & $\begin{array}{l}\text { Proportion } \\
\text { of fixed } \\
\text { asset to } \\
\text { total asset }\end{array}$ \\
\hline \multirow{2}{*}{ Log of minimum wages } & $2.242^{* \star *}$ & 0.008 & $0.166^{\star \star}$ & -0.139 & $2.068^{\star \star *}$ & $0.247^{\star \star \star}$ \\
\hline & $(0.580)$ & $(0.012)$ & $(0.069)$ & $(0.080)$ & $(0.144)$ & $(0.012)$ \\
\hline \multirow{2}{*}{$\begin{array}{l}\text { Log of minimum wages * } \log \\
\text { of the number of laborers in } \\
2008\end{array}$} & $-0.968^{* * *}$ & $0.020^{\star \star *}$ & 0.028 & $0.124^{\star *}$ & $-0.532^{\star \star \star}$ & $-0.029^{* * *}$ \\
\hline & $(0.197)$ & $(0.003)$ & $(0.046)$ & $(0.049)$ & $(0.059)$ & $(0.003)$ \\
\hline \multirow{2}{*}{ Year 2009} & $-0.006^{\star *}$ & $0.006^{\star * *}$ & $0.010^{\star \star * *}$ & $0.255^{\star \star \star}$ & $0.062^{* \star \star}$ & -0.003 \\
\hline & $(0.002)$ & $(0.002)$ & $(0.003)$ & $(0.005)$ & $(0.005)$ & $(0.004)$ \\
\hline \multirow{2}{*}{ Year 2010} & 0.012 & $0.012^{* * *}$ & $0.054^{\star \star *}$ & $0.349^{* \star *}$ & $0.253^{* * *}$ & $-0.021^{* *}$ \\
\hline & $(0.016)$ & $(0.003)$ & $(0.010)$ & $(0.005)$ & $(0.023)$ & $(0.009)$ \\
\hline \multirow{2}{*}{$\begin{array}{l}\text { Log of regional CPI in } \\
\text { previous year }\end{array}$} & 0.001 & $0.000^{* * *}$ & 0.000 & -0.001 & $0.002^{* *}$ & 0.000 \\
\hline & $(0.001)$ & $(0.000)$ & $(0.000)$ & $(0.000)$ & $(0.001)$ & $(0.000)$ \\
\hline \multirow{2}{*}{$\begin{array}{l}\text { Log of lagged labor force of } \\
\text { provinces }\end{array}$} & -0.010 & $-0.022^{*}$ & $-0.082^{* * *}$ & $-0.407^{\star * *}$ & 0.043 & -0.009 \\
\hline & $(0.010)$ & $(0.014)$ & $(0.002)$ & $(0.061)$ & $(0.156)$ & $(0.016)$ \\
\hline \multirow{6}{*}{$\begin{array}{l}\text { Log of lagged gross output } \\
\text { of agriculture per capita of } \\
\text { provinces } \\
\text { Log of lagged gross output } \\
\text { of industry per capita of } \\
\text { provinces } \\
\text { Log of lagged gross output } \\
\text { of service per capita of } \\
\text { provinces }\end{array}$} & $0.407^{\star \star \star}$ & $-0.030^{\star *}$ & $0.200^{\star *}$ & 0.131 & $0.562^{\star \star \star}$ & -0.015 \\
\hline & $(0.066)$ & $(0.012)$ & $(0.094)$ & $(0.087)$ & $(0.169)$ & $(0.024)$ \\
\hline & $0.047^{*}$ & $-0.010^{* * *}$ & -0.001 & $0.144^{\star \star *}$ & $-0.065^{\star * *}$ & $-0.025^{* * *}$ \\
\hline & $(0.027)$ & $(0.002)$ & $(0.011)$ & $(0.032)$ & $(0.017)$ & $(0.005)$ \\
\hline & $0.044^{*}$ & 0.004 & $0.013^{* *}$ & 0.002 & -0.024 & $-0.026^{* * *}$ \\
\hline & $(0.026)$ & $(0.004)$ & $(0.006)$ & $(0.004)$ & $(0.036)$ & $(0.005)$ \\
\hline \multirow{2}{*}{$\begin{array}{l}\text { Log of lagged regional } \\
\text { average wages }\end{array}$} & 0.016 & -0.007 & $-0.254^{\star * *}$ & $-0.601^{* *}$ & $0.206^{\star *}$ & $-0.068^{*}$ \\
\hline & $(0.113)$ & $(0.011)$ & $(0.019)$ & $(0.069)$ & $(0.079)$ & $(0.037)$ \\
\hline \multirow{2}{*}{ Constant } & $3.147^{\star \star \star}$ & 0.160 & $1.816^{\star * \star}$ & $17.361^{* \star *}$ & $7.485^{\star * *}$ & -0.053 \\
\hline & $(0.313)$ & $(0.161)$ & $(0.139)$ & $(0.241)$ & $(0.489)$ & $(0.214)$ \\
\hline Observations & 447,245 & 447,245 & 447,245 & 447,245 & 447,245 & 447,245 \\
\hline R-squared & 0.046 & 0.005 & 0.021 & 0.085 & 0.091 & 0.004 \\
\hline The number of firms & 155,590 & 155,590 & 155,590 & 155,590 & 155,590 & 155,590 \\
\hline \multicolumn{7}{|c|}{$\begin{array}{l}\text { Note: All monetary variables are measured in the January } 2008 \text { price. } \\
\text { *** } p<0.01,{ }^{* *} p<0.05,{ }^{*} p<0.1 . \\
\text { Robust Driscoll-Kraay standard errors in parentheses. } \\
\text { Source: Estimation from EC } 2008, E C 2009 \text { and EC } 2010 .\end{array}$} \\
\hline
\end{tabular}

